\title{
Chronic Viral Infection and Primary Central Nervous System Malignancy
}

\author{
Robert Saddawi-Konefka • John R. Crawford
}

Received: 23 November 2009 / Accepted: 5 March 2010/Published online: 13 April 2010

(C) The Author(s) 2010. This article is published with open access at Springerlink.com

\begin{abstract}
Primary central nervous system (CNS) tumors cause significant morbidity and mortality in both adults and children. While some of the genetic and molecular mechanisms of neuro-oncogenesis are known, much less is known about possible epigenetic contributions to disease pathophysiology. Over the last several decades, chronic viral infections have been associated with a number of human malignancies. In primary CNS malignancies, two families of viruses, namely polyomavirus and herpesvirus, have been detected with varied frequencies in a number of pediatric and adult histological tumor subtypes. However, establishing a link between chronic viral infection and primary CNS malignancy has been an area of considerable controversy, due in part to variations in detection frequencies and methodologies used among researchers. Since a latent viral neurotropism can be seen with a variety of viruses and a widespread seropositivity exists among the population, it has been difficult to establish an association between viral infection and CNS malignancy based on epidemiology alone. While direct evidence of a role of viruses in neurooncogenesis in humans is lacking, a more plausible hypothesis of neuro-oncomodulation has been proposed. The overall goals of this review are to summarize the many human investigations that have studied viral infection in primary CNS tumors, discuss potential neuro-oncomodulatory mechanisms of viral-associated CNS disease and propose future research
\end{abstract}

R. Saddawi-Konefka

School of Medicine,

University of California,

San Diego, CA, USA

\section{J. R. Crawford $(\triangle)$}

Department of Neurosciences and Pediatrics,

University of California,

San Diego, CA, USA

e-mail: jrcrawford@ucsd.edu directions to establish a more firm association between chronic viral infections and primary CNS malignancies.

Keywords neuro-oncology · polyomavirus · herpesvirus . brain tumor $\cdot$ central nervous system

\section{Introduction}

Primary central nervous system (CNS) tumors occur at an incidence of 16.5 cases $/ 100,000$ person-years, of which approximately $27 \%$ represent children less than 19 years old (CBTRUS 2009). Primary CNS tumors occur more in men (3.7/100,000 person-years) than in women (2.6/ 100,000-person-years; GLOBOCAN 2002; Parkin et al. 2002) and are composed of a diverse set of histological and biochemical features, each associated with its own morbidity and mortality despite multimodality treatment with surgery, radiation, chemotherapy, and biologic approaches. In the USA, the mortality rates for primary malignant brain tumors ranges from 3.7-5.6 per 100,000 with 25-29\% 5 and 10-year survival, respectively, according to American Cancer Society statistics (http://www.cancer.org/statistics/). In terms of epidemiologic etiologies of primary brain tumors, many potential risk factors have been studied including genetic susceptibility (genetic syndromes or gene-specific polymorphisms), radiation exposure (ionizing and non-ionizing electromagnetic fields), neuro-carcinogens, allergic diseases, and viral infections (Wrensch et al. 2002; Bondy et al. 2008). Since viral infections have been associated with other systemic human malignancies including hepatitis $\mathrm{B} / \mathrm{C}$ (hepatocellular carcinoma), Epstein Barr virus (EBV; $\mathrm{B}+\mathrm{T}$ cell lymphoma, post-transplant lymphoproliferative disease, leiomyosarcoma, nasopharyngeal carcinoma), human papillomavirus (cervical carcinoma), human herpesvirus-8 (HHV-8; Kaposi sarcoma), and human T 
cell lymphotropic virus type 1 ( $\mathrm{T}$ cell leukemia), it is not unreasonable to hypothesize a role for viral infections in CNS malignancies (Liao 2006). With regards to viral etiologies of primary CNS tumors, the polyomavirus and herpesvirus families have been among the most widely studied. Over the past few decades, the interest in the polyomavirus family of viruses has grown in parallel to both the viruses' association with human brain tumors and oncogenecity in experimental animals (Croul et al. 2003; White et al. 2005; Ahsan and Shah 2006; Jiang et al. 2009). Among the members of the polyomavirus family, the three that have been detected most widely in both pediatric and adult histological subtypes of primary CNS brain tumors are the $\mathrm{JC}$ virus (JCV), BK virus (BKV), and Simian vacuolating virus 40 (SV40; Croul et al. 2003; White et al. 2005; Barbanti-Brodano et al. 2006; Lee and Langhoff 2006). The more recently discovered members of the polyomavirus family (KI, WU, and MC) have yet to be studied in association with human brain tumors (zur Hausen 2008; Dalianis et al. 2009). The polyomavirus family is of considerable interest in its potential role in neuro-oncogenesis since it has been shown to induce brain tumors in animal models (Rollison et al. 2003; Rollison 2006). The herpesvirus family is a functionally and structurally diverse group consisting of eight known human variants (herpes simplex 1-2; varicella zoster virus, Epstein Barr, human cytomegalovirus, human herpesviruses 6,7 , and 8) and has been associated with a number of human diseases (Arvin et al. 2007). Since many of the herpesviruses can establish lifelong latency in the CNS, whereby only a limited number of viral genes are expressed without production of progeny virions and lytic infection, it is plausible to hypothesize that herpesviruses, among others, may play a role in CNS neuro-oncogenesis. In this comprehensive review of chronic viral infections and primary CNS malignancy, we hope to summarize the numerous published results both in support and in contradictory to the role of chronic viral infection in human primary CNS malignancies. Furthermore, we would like to address potential neurooncologic molecular mechanisms of disease related to the specific viruses reported in CNS tumors. Finally, we hope to address the many controversies and propose future research directions that promote a greater understanding of neurovirology in the area of neuro-oncology research.

\section{Detection of human herpesviruses in primary CNS malignancy}

Herpes simplex 1, 2

Human herpes simplex viruses 1 and 2 (HSV-1/2), members of the alphaherpesvirus family of DNA viruses, are between 152-154 kbp (McGeoch et al. 1988; Dolan et al. 1998). HSV-1/2 infection is most notable for its role in CNS encephalitis (Kimberlin 2006). Surprisingly, most of the data on HSV-1/2 infection and primary CNS tumors comes from serological $\mathrm{IgG}$ antibody studies by enzyme-linked immunosorbent assay as summarized in Table 1. Between $79.6-82 \%$ of patients with glioblastoma multiforme (GBM) were seropositive for HSV-1/2 compared with $58-72 \%$ of other tumor brain tumor types and $76.1-79.6 \%$ of non-tumor controls (Wrensch et al. 2001, 2005). A high percentage of seropositivity $(86 \%)$ has also been reported in a series of 72 primary CNS glioma, meningioma, and acoustic schwanomma (Poltermann et al. 2006). Viral nucleic acid detection of HSV-1/2 by real-time quantitative PCR revealed $2.8 \%$ positivity in low-grade pilocytic astrocytomas $(N=35$; Neves et al. 2008). Only a small number of primary CNS tumors have been tested for HSV-1/2 by in situ hybridization (ISH), and all have been negative (Cobbs et al. 2002). To our knowledge, there has not been a detailed immunohistochemistry (IHC) analysis performed on a series of primary CNS tumors to assess for HSV-1/2 viral antigen.

\section{Varicella zoster virus}

Varicella zoster virus (VZV), another member of the alphaherpesvirus family, is smaller in size than HSV-1/2 and exhibits neuronal latency (Davison and Scott 1986). VZV DNA has been detected in $5.7 \%$ of pilocytic astrocytoma (2/35) compared with $0 / 10$ non-tumor control brain and without IHC correlate (Table 1). The more interesting data on the role of VZV and primary CNS tumors comes from epidemiologic studies comparing the frequency of serum IgG positivity in GBM, other brain tumor subtypes, and non-brain tumor controls. Wrensch et al. first demonstrated an inverse correlation between VZV $\operatorname{IgG}$ positivity in brain tumors (56/78) and non-tumor controls (73/89) (Wrensch et al. 1997). The observed findings in GBM were reproduced in a subsequent study and revealed 38/46 anti-VZV IgG positive versus $137 /$ 139 non-brain tumor control sera (Wrensch et al. 2001). A third larger study revealed no changes in the degree of anti-VZV IgG positivity between GBM and non-tumor sera (109/115 vs. 282/289), however when stratifying based on viral titer quartile, the inverse relationship was maintained (Wrensch et al. 2005). While the authors mention that these findings could be related to the exclusion of patients on high-dose corticosteroids, the trends are reproducible and are worthy of a larger multiinstitutional analysis to explore the possibility of a "neuroprotective effect" of VZV immunoglobulin detection in GBM. 
Table 1 Detection of human herpesviruses in primary central nervous system malignancy

\begin{tabular}{|c|c|c|c|c|c|}
\hline $\begin{array}{l}\text { Herpesvirus } \\
\text { subtype }\end{array}$ & Tumor histology subtypes & $\begin{array}{l}\text { Serum viral IgG antibody detection } \\
\text { (ELISA) }\end{array}$ & $\begin{array}{l}\text { Viral nucleic acid detection (PCR, } \\
\text { nPCR, qPCR, ISH) }\end{array}$ & Viral protein detection (IHC) & Reference \\
\hline \multirow[t]{5}{*}{$\begin{array}{l}\text { HHV } 1-2 \\
\quad(H S V 1 / 2)\end{array}$} & $\begin{array}{l}\text { GBM }(N=45) \text {, other glial } \\
\text { subtypes }(N=43)\end{array}$ & $\begin{array}{l}37 / 45 \mathrm{GBM}+25 / 43 \text { other glial } \\
\text { subtypes }+90 / 113 \text { non-tumor } \\
\text { controls }+\end{array}$ & NP & NP & $\begin{array}{l}\text { Wrensch et } \\
\text { al. } 2001\end{array}$ \\
\hline & $\begin{array}{l}\text { GBM }(N=113) \text {, other brain } \\
\text { tumor subtypes }(N=111)\end{array}$ & $\begin{array}{l}90 / 113 \text { GBM }+79 / 111 \text { other brain } \\
\text { tumor subtypes }+, 217 / 285 \text { non- } \\
\text { tumor controls }+\end{array}$ & NP & NP & $\begin{array}{l}\text { Wrensch et } \\
\text { al. } 2005\end{array}$ \\
\hline & Pilocytic astrocytoma $(N=35)$ & $\mathrm{NP}$ & $\begin{array}{l}\text { 1/35 Pilocytic astrocytoma }+, 2 / 10 \\
\text { non-tumor control }+ \text { by qPCR }\end{array}$ & NP & $\begin{array}{l}\text { Neves et } \\
\text { al. } 2008\end{array}$ \\
\hline & $\begin{array}{l}\text { Glial tumors }(N=35) \\
\text { meningiomas }(N=31) \\
\text { acoustic schwanommas } \\
(N=6)\end{array}$ & $62 / 72$ Total tumors + & NP & NP & $\begin{array}{l}\text { Poltermann } \\
\text { et al. } \\
2006\end{array}$ \\
\hline & $\begin{array}{l}\text { GBM }(N=3) \text { diffuse fibrillary } \\
\text { astrocytoma }(N=2)\end{array}$ & NP & $\begin{array}{l}0 / 3 \mathrm{GBM}+, 0 / 2 \text { diffuse fibrillary } \\
\text { astrocytoma }+, 0 / 3 \text { normal brain } \\
\text { + by ISH }\end{array}$ & NP & $\begin{array}{l}\text { Cobbs et } \\
\text { al. } 2002\end{array}$ \\
\hline \multirow[t]{5}{*}{$\begin{array}{l}\text { HHV-3 } \\
\text { (VZV) }\end{array}$} & Glial tumors $(N=78)$ & $\begin{array}{l}\text { 56/78 Glial tumors }+, 73 / 89 \text { non- } \\
\text { brain tumor controls }+\end{array}$ & $\mathrm{NP}$ & NP & $\begin{array}{l}\text { Wrensch et } \\
\text { al. } 1997\end{array}$ \\
\hline & $\begin{array}{l}\operatorname{GBM}(N=46) \text { other brain tumor } \\
\quad \text { subtypes }(N=68)\end{array}$ & $\begin{array}{l}38 / 46 \mathrm{GBM}+, 63 / 68 \text { other brain } \\
\text { tumor subtypes }+, 137 / 139 \text { non- } \\
\text { brain tumor controls }+\end{array}$ & NP & NP & $\begin{array}{l}\text { Wrensch et } \\
\text { al. } 2001\end{array}$ \\
\hline & $\begin{array}{l}\text { GBM }(N=115) \text {, other brain } \\
\text { tumor subtypes }(N=114)\end{array}$ & $\begin{array}{l}\text { 109/115 GBM+, } 110 / 114 \text { other } \\
\text { brain tumor subtypes }+, 282 / 289 \\
\text { non-brain tumor control }+\end{array}$ & NP & NP & $\begin{array}{l}\text { Wrensch et } \\
\text { al. } 2005\end{array}$ \\
\hline & Pilocytic astrocytoma $(N=35)$ & NP & $\begin{array}{l}\text { 2/35 Pilocytic Astrocytoma+, 0/ } \\
10 \text { Non-Tumor Control+ by } \\
\text { qPCR }\end{array}$ & NP & $\begin{array}{l}\text { Neves et } \\
\text { al. } 2008\end{array}$ \\
\hline & $\begin{array}{l}\text { Glial tumors }(N=35) \\
\text { meningiomas }(N=31) \\
\text { acoustic schwanommas } \\
(N=6)\end{array}$ & $66 / 72$ Total tumors + & NP & NP & $\begin{array}{l}\text { Poltermann } \\
\text { et al. } \\
2006\end{array}$ \\
\hline \multirow[t]{4}{*}{$\begin{array}{l}\mathrm{HHV}-4 \\
\quad(\mathrm{EBV})\end{array}$} & $\begin{array}{l}\operatorname{GBM}(N=48) \text { other brain tumor } \\
\quad \text { subtypes }(N=69)\end{array}$ & $\begin{array}{l}\text { 41/48 GBM+, } 62 / 69 \text { other brain } \\
\text { Ttumor subtypes }+, 139 / 151 \text { non- } \\
\text { brain tumor control+ }\end{array}$ & NP & NP & $\begin{array}{l}\text { Wrensch et } \\
\text { al. } 2001\end{array}$ \\
\hline & $\begin{array}{l}\text { GBM }(N=115) \text {, other brain } \\
\text { tumor subtypes }(N=113)\end{array}$ & $\begin{array}{l}\text { 106/115 GBM+, } 105 / 113 \text { other } \\
\text { brain tumor subtypes }+, 266 / 283 \\
\text { non-brain tumor control }+\end{array}$ & NP & NP & $\begin{array}{l}\text { Wrensch et } \\
\text { al. } 2005\end{array}$ \\
\hline & Pilocytic astrocytoma $(N=35)$ & $\mathrm{NP}$ & $\begin{array}{l}\text { 9/35 Pilocytic Astrocytoma }+, 7 / 9 \\
\text { Non-Tumor Control+ by qPCR }\end{array}$ & NP & $\begin{array}{l}\text { Neves et } \\
\text { al. } 2008\end{array}$ \\
\hline & $\begin{array}{l}\text { Glial tumors }(N=35) \text {, } \\
\text { meningiomas }(N=31) \\
\text { acoustic schwanommas } \\
(N=6)\end{array}$ & $64 / 72$ Total tumors + & NP & NP & $\begin{array}{l}\text { Poltermann } \\
\text { et al. } \\
2006\end{array}$ \\
\hline \multirow[t]{2}{*}{$\begin{array}{l}\text { HHV-5 } \\
\text { (CMV) }\end{array}$} & $\begin{array}{l}\text { GBM, anaplastic astrocytoma, } \\
\text { diffuse fibrillary astrocytoma, } \\
\text { meningioma }\end{array}$ & NP & $\begin{array}{l}\text { 7/9GBM+ }(\mathrm{nPCR}) ; 12 / 12 \mathrm{GBM} \\
+, 4 / 4 \text { diffuse fibrillary } \\
\text { astrocytoma }+, 0 / 5 \text { meningioma } \\
+, 0 / 8 \text { normal brain, } 0 / 9 \text { other } \\
\text { neurological diseases (ISH) }\end{array}$ & $\begin{array}{l}\text { 38/38 } \mathrm{GBM}+, 1 / 1 \text { anaplastic } \\
\text { astrocytoma, } 6 / 6 \text { diffuse fibrillary } \\
\text { astrocytoma }+, 0 / 9 \text { meningioma }+, 0 / 6 \\
\text { normal brain, } 0 / 9 \text { other neurological } \\
\text { diseases (IHC using } 3 \text { antibodies) }\end{array}$ & $\begin{array}{l}\text { Cobbs et } \\
\text { al. } 2002\end{array}$ \\
\hline & $\begin{array}{l}\text { GBM, primary GBM cell } \\
\text { culture }\end{array}$ & & & & \\
\hline \multirow[t]{4}{*}{$\begin{array}{l}\text { Peripheral } \\
\text { blood } \\
\text { samples }\end{array}$} & $\mathrm{NP}$ & $\begin{array}{l}\text { 29/68 GBM+, } 22 / 34 \text { primary GBM } \\
\text { cell culture+ (nPCR with } 2 \\
\text { primers);16/16 GBM+ (ISH);16/ } \\
20 \text { peripheral blood }+, 0 / 17 \text { non- } \\
\text { tumor controls }+ \text { (PCR) }\end{array}$ & $\begin{array}{l}\text { 72/78 GBM+, } 16 / 16 \text { primary } \\
\text { GBM cell cultures }+(\text { IHC using } \\
\text { two antibodies) }\end{array}$ & & $\begin{array}{l}\text { Mitchell et } \\
\text { al. } 2008\end{array}$ \\
\hline & $\begin{array}{l}\text { GBM }(N=21) \text {, anaplastic } \\
\text { astrocytoma }(N=12) \text {, low- } \\
\text { grade glioma }(N=17)\end{array}$ & NP & NP & $\begin{array}{l}21 / 21 \mathrm{GBM}+, 9 / 12 \text { anaplastic } \\
\text { astrocytoma }+, 14 / 17 \text { low-grade glioma } \\
+, 0 / 6 \text { non-brain tumor controls }+ \\
\text { (IHC) }\end{array}$ & $\begin{array}{l}\text { Scheurer et } \\
\text { al. } 2008\end{array}$ \\
\hline & $\begin{array}{l}\text { Glial tumors }(N=35) \\
\text { meningiomas }(N=31) \\
\text { acoustic schwanommas } \\
(N=6)\end{array}$ & 46/72 Total Tumors + & $\begin{array}{l}0 / 72 \text { Total tumors }+ \text { (nPCR with } \\
\text { two primers) }\end{array}$ & $\begin{array}{l}0 / 72 \text { Total tumors }+ \text { (IHC using } 2 \\
\text { antibodies) }\end{array}$ & $\begin{array}{l}\text { Poltermann } \\
\text { et al. } \\
2006\end{array}$ \\
\hline & $\begin{array}{l}\text { GBM }(N=8) \text {, diffuse fibrillary } \\
\text { astrocytoma }(N=3), \\
\text { anaplastic astrocytoma }(N=\end{array}$ & NP & $\begin{array}{l}0 / 22 \text { Total tumors }+, 0 / 4 \text { normal } \\
\text { brain }+, 0 / 24 \text { other neurological } \\
\text { diseases }+(\mathrm{nPCR}, \mathrm{ISH})\end{array}$ & $\begin{array}{l}\text { 0/22 Total tumors }+, 0 / 4 \text { normal brain }+ \text {, } \\
\text { 0/24 other neurological diseases }+ \\
\text { (IHC) }\end{array}$ & $\begin{array}{l}\text { Lau et al. } \\
2005\end{array}$ \\
\hline
\end{tabular}

2), ependymoma $(N=3)$ 
Table 1 (continued)

\begin{tabular}{|c|c|c|c|c|c|}
\hline $\begin{array}{l}\text { Herpesvirus } \\
\text { subtype }\end{array}$ & Tumor histology subtypes & $\begin{array}{l}\text { Serum viral IgG antibody detection } \\
\text { (ELISA) }\end{array}$ & $\begin{array}{l}\text { Viral nucleic acid detection (PCR, } \\
\text { nPCR, qPCR, ISH) }\end{array}$ & Viral protein detection (IHC) & Reference \\
\hline & $\begin{array}{l}\text { GBM }(N=97), \text { ependymoma } \\
\qquad(N=15), \text { oligodendroglioma } \\
(N=20)\end{array}$ & NP & $\begin{array}{r}\text { 7/97 GBM }+, 0 / 15 \text { ependymoma }+, \\
0 / 20 \text { oligodendroglioma }+ \text { (ISH) }\end{array}$ & $\begin{array}{l}\text { 9/97 GBM+ }+0 / 15 \text { ependymoma }+, 0 / 20 \\
\text { oligodendroglioma }+(\text { ISH) }\end{array}$ & $\begin{array}{c}\text { Sabatier et } \\
\text { al. } 2005\end{array}$ \\
\hline & $\begin{array}{l}\text { GBM }(N=37) \text { other brain tumor } \\
\text { subtypes }(N=39)\end{array}$ & $\begin{array}{l}\text { 24/37 GBM+, } 20 / 39 \text { other brain } \\
\text { tumor subtypes }+, 54 / 94 \text { non- } \\
\text { brain tumor control+ }\end{array}$ & NP & NP & $\begin{array}{l}\text { Wrensch et } \\
\text { al. } 2001\end{array}$ \\
\hline & $\begin{array}{l}\text { GBM }(N=115), \text { other brain } \\
\text { tumor subtypes }(N=113)\end{array}$ & $\begin{array}{l}\text { 71/115 GBM+, } 61 / 113 \text { other brain } \\
\text { tumor subtypes }+, 163 / 287 \text { non- } \\
\text { brain tumor control }+\end{array}$ & NP & NP & $\begin{array}{l}\text { Wrensch et } \\
\text { al. } 2005\end{array}$ \\
\hline \multirow[t]{7}{*}{ HHV-6 } & $\begin{array}{l}\text { Extensive series of glial and } \\
\text { neuronal Tumors }(N=98)\end{array}$ & $\mathrm{NP}$ & $\begin{array}{l}\text { 4/36 Meningioma }+, 1 / 18 \mathrm{GBM}+ \\
3 / 5 \text { ependymoma }+(\mathrm{nPCR})\end{array}$ & & $\begin{array}{l}\text { Chan et al. } \\
1999\end{array}$ \\
\hline & $\begin{array}{l}\text { Glial and neuronal tumor } \\
\text { subtypes }(N=37)\end{array}$ & NP & 6/37 Total tumors + (nPCR) & NP & $\begin{array}{l}\text { Luppi et al. } \\
1995\end{array}$ \\
\hline & $\begin{array}{l}\text { Extensive series of glial and } \\
\text { neuronal tumors }(N=118)\end{array}$ & $\begin{array}{l}\text { 90/115 Total tumors }+, 106 / 150 \\
\text { non-tumor controls }+\end{array}$ & $\begin{array}{l}\text { 14/31 GBM+, } 2 / 2 \text { neuroblastoma } \\
+, 9 / 35 \text { meningioma }+, 1 / 2 \\
\text { ependymoma }+, 2 / 6 \text { astrocytoma } \\
+, 15 / 39 \text { other brain tumor } \\
\text { subtypes }+(\mathrm{nPCR})\end{array}$ & 4/10 Tumors+ (IHC) & $\begin{array}{r}\text { Cuomo et } \\
\text { al. } 2001\end{array}$ \\
\hline & $\begin{array}{l}\text { Pediatric pilocytic astrocytoma } \\
\qquad(N=35)\end{array}$ & NP & $\begin{array}{l}\text { 0/35 Pilocytic astrocytoma }+, 0 / 10 \\
\text { non-tumor control+ by qPCR }\end{array}$ & NP & $\begin{array}{l}\text { Neves et } \\
\text { al. } 2008\end{array}$ \\
\hline & $\begin{array}{l}\text { Extensive series of pediatric } \\
\text { glial and neuronal tumors } \\
(N=150)\end{array}$ & NP & $\begin{array}{l}\text { 141/240 Total tumors }+, 18 / 64 \\
\text { non-brain tumor controls }+ \\
\text { (nPCR with two primers); } 83 \text { / } \\
150 \text { total tumors }+, 10 / 32 \text { non- } \\
\text { brain tumor controls }+ \text { (ISH) }\end{array}$ & $\begin{array}{l}\text { 50/124 Total tumors }+, 6 / 32 \text { non-brain } \\
\text { tumor controls }+(\text { IHC) }\end{array}$ & $\begin{array}{l}\text { Crawford } \\
\text { et al. } \\
\text { 2009a }\end{array}$ \\
\hline & $\begin{array}{l}\text { Extensive series of pediatric } \\
\text { glial and neuronal tumors } \\
(N=282)\end{array}$ & NP & $\begin{array}{l}\text { 14/30 Total tumors }+, 0 / 25 \text { non- } \\
\text { tumor controls }+(\mathrm{nPCR}) ; 106 \text { / } \\
224 \text { total tumors }+, 0 / 25 \text { non- } \\
\text { tumor controls }+(\mathrm{ISH})\end{array}$ & $\begin{array}{l}\text { 150/559 Total tumors }+, 0 / 25 \text { non-tumor } \\
\text { controls }+ \text { (IHC with two antibodies) }\end{array}$ & $\begin{array}{l}\text { Crawford } \\
\text { et al. } \\
2009 b\end{array}$ \\
\hline & $\begin{array}{l}\text { GBM }(N=23) \text {, anaplastic } \\
\text { astrocytoma }(N=3), \\
\text { anaplastic oligodendroglioma } \\
(N=2) \text {, medulloblastoma } \\
(N=12)\end{array}$ & NP & $\begin{array}{l}\text { 0/41 Total tumors }+ \text { (by digital } \\
\text { karyotyping) }\end{array}$ & NP & $\begin{array}{r}\text { Duncan et } \\
\text { al. } 2009\end{array}$ \\
\hline \multirow[t]{2}{*}{ HHV-7 } & $\begin{array}{l}\text { Extensive series of glial and } \\
\text { neuronal tumors }(N=98)\end{array}$ & NP & $\begin{array}{l}\text { 5/36 Meningioma }+, 3 / 18 \mathrm{GBM}+\text {, } \\
1 / 5 \text { ependymoma }+, 1 / \\
8 \text { schwannoma }+, 2 / 16 \text { other } \\
\text { astrocytoma }+, 2 / 5 \text { other brain } \\
\text { tumors }+(\mathrm{nPCR})\end{array}$ & & $\begin{array}{l}\text { Chan et al. } \\
1999\end{array}$ \\
\hline & $\begin{array}{l}\text { Pediatric pilocytic astrocytoma } \\
\qquad(N=35)\end{array}$ & NP & $\begin{array}{l}\text { 1/35 Pilocytic astrocytoma }+, 0 / 6 \\
\text { non-tumor control+ by qPCR }\end{array}$ & NP & $\begin{array}{l}\text { Neves et } \\
\text { al. } 2008\end{array}$ \\
\hline $\begin{array}{l}\text { HHV-8 } \\
\text { (KSV) }\end{array}$ & $\begin{array}{l}\text { Pediatric pilocytic astrocytoma } \\
\qquad(N=35)\end{array}$ & NP & $\begin{array}{l}\text { 0/35 Pilocytic astrocytoma }+, 0 / 6 \\
\text { non-tumor control+ by qPCR }\end{array}$ & NP & $\begin{array}{l}\text { Neves et } \\
\text { al. } 2008\end{array}$ \\
\hline
\end{tabular}

Abbreviations: $N P$ not performed, ELISA enzyme-linked immunosorbent assay, $P C R$ polymerase chain reaction, $n P C R$ nested polymerase chain reaction, $q P C R$ real-time quantitative polymerase chain reaction, $I S H$ in situ hybridization, $I H C$ immunohistochemistry, $G B M$ glioblastoma multiforme

\section{Epstein Barr Virus}

EBV, a member of the gamma herpesvirus family, is present in greater than $90 \%$ of the population and is characterized by its persistence largely in lymphocytes (Volpi 2004). EBV has been detected in greater than $95 \%$ of primary CNS lymphoma in HIV-related disease and 5\% of CNS lymphoma in immunocompetent hosts (Gulley 2001). Seropositivity for EBV is high in sera of patients with GBM (85-92\%), other CNS tumor subtypes (90-93\%), and non-tumor control sera (92-94\%; Wrensch et al. 2001; Wrensch et al. 2005; Poltermann et al. 2006). Interestingly,
Neves et al. reported 9/35 EBV-positive pilocytic astrocytomas by quantitative PCR (their highest for any herpesvirus tested), however seven of nine normal cerebellum were also were positive by PCR (Neves et al. 2008; Table 1). Like HSV-1/2, there are no published reports on the frequency of EBV viral antigens in non-CNS lymphoma tumors by IHC.

\section{Human cytomegalovirus}

Human cytomegalovirus (CMV), a member of the betaherpesvirus family, has been the most studied and perhaps the 
most controversial of all the herpesviruses associated with primary CNS tumors (Miller 2009). In terms of CMV IgG seropositivity in patients with primary CNS tumors, there has been a slight non-significant increase in positivity among patients with GBM (62-66\%) compared to sera from other CNS malignancies (51-54\%) or non-tumor control sera $(57 \%)$ (Wrensch et al. 2001; 2005). Much of the published data in support of a role for CMV in CNS tumorigenesis comes from the detection of viral nucleic acids by PCR and ISH and proteins by IHC (Table 1). Cobbs et al. first reported a strong association between CMV and GBM (Cobbs et al. 2002). Using nested PCR with primers for the UL55 glycoprotein B gene, they reported positivity in 7/9 GBMs. ISH was used to confirm PCR findings with both whole-genome CMV primers (4/4 GBM, 2/2 diffuse fibrillary astrocytoma) and immediate early gene CMV primers (8/8 GBM, $2 / 2$ diffuse fibrillary astrocytoma). CMV was not detected in normal control brain by PCR or ISH in this study (Cobbs et al. 2002). The strong association of $\mathrm{CMV}$ and GBM was further demonstrated by IHC using IEI-72 immediate early antibody (22/22), p52/76 immediate early/early antigen antibody (8/8), and pp65 tegument protein antibody $(8 / 8$; Cobbs et al. 2002). Similar IHC results were observed in other glial tumor subtypes (6/6 diffuse fibrillary astrocytoma, 1/1 anaplastic astrocytoma), but not in non-glial tumors (0/9 meningioma), non-tumor brain $(0 / 6)$, or brain from other neurological diseases (0/9; Cobbs et al. 2002). On the contrary, Sabatier et al. reported that less than $10 \%$ of GBMs in their French series were positive for CMV by either ISH (7/97) or IHC (9/97; Sabatier et al. 2005). This study was followed by two other studies that failed to detect CMV in a series of 22 (Lau et al. 2005) or 72 (Poltermann et al. 2006) GBMs by PCR, ISH, or IHC using two different antibodies. More recently, two groups have reported widespread detection of CMV in GBM using similar techniques described by Cobbs et al. (Mitchell et al. 2008; Scheurer et al. 2008). Scheurer et al. reported strong positivity for CMV by IHC in GBM $(21 / 21)$, anaplastic astrocytoma (9/12), and low-grade astrocytoma (14/17) compared with non-tumor brain controls (0/6; Scheurer et al. 2008). Mitchell et al. reported strong positivity of GBMs by nested PCR (29/ 68), ISH (16/16), and IHC (72/78) compared with nontumor controls. Additionally, Mitchell et al. reported similar finding in short-term primary glioblastoma cultures $(23 / 34 \mathrm{PCR}+, 16 / 16 \mathrm{IHC}+)$ and in peripheral blood of patients with GBM (16/20) compared with controls (Mitchell et al. 2008). It has been suggested that tissue processing, amount of template DNA used for PCR, and concentrations and conditions of IHC methodology may all be possible explanations for discrepancies among researchers (Scheurer et al. 2007).
Human Herpesvirus-6

Human herpesvirus-6 (HHV-6) is a member of the betaherpesvirus and exists as two variants A (HHV6-A) and B (HHV6-B; Caserta 2004; De Bolle et al. 2005). HHV- 6 B is the causative agent of the common viral exanthematous disease roseola infantum (Yamanishi et al. 1988), while HHV-6 A has been shown to have more neurotropic features (Hall et al. 1998), including altering cytokine synthesis in astrocyte cell lines (Yoshikawa et al. 2002). Initially discovered as a B cell lymphotropic virus, chromosomally integrated forms of HHV-6 have been recognized and may play a role in disease pathogenesis (Clark and Ward 2008; Hall et al. 2008). In terms of HHV-6 seroprevalence, greater than $90 \%$ of humans become seropositive within the first year of life (Okuno et al. 1989; Hall et al. 1994; Zerr et al. 2005). Regarding primary CNS tumors, one study revealed significant differences in seroreactivity measured by indirect immunofluorescence in brain tumor patients $(90 / 115)$ versus controls $(106 / 150)$ (Cuomo et al. 2001). The same study reported HHV-6 PCR positivity in $45 \%$ of GBMs $(14 / 31)$ and $4 / 10$ tumors expressed early HHV-6 viral antigen p41 detected by IHC (Table 1). Others have reported between $14-16 \%$ of brain tumor samples were positive by nested PCR (Luppi et al. 1995; Chan et al. 1999). Most recently, we reported the detection of HHV-6 in a large series of previously untreated fresh frozen and paraffin-embedded pediatric primary CNS brain tumors by nested PCR, ISH, and IHC (Crawford et al. 2009a). HHV-6 variants were detected in tumors by nested PCR (59\%), ISH (55\%), and IHC (40\%), significantly more than age-matched non-tumor brain. Interestingly, the low-grade gliomas showed significantly higher immunopositivity for the HHV-6 glycoprotein gp116/64/54 than higher-grade glial and non-glial tumor subtypes. We reported similar frequencies of HHV-6 positivity by nested PCR (47\%), ISH (47\%), and ICH (27\%) in a large adult cohort of paraffin-embedded brain tumors (Crawford et al. 2009b). In both studies, the glial tumors were significantly more positive by IHC than non-glial tumors, and there was a predominance of HHV6-A confirmed by sequence analysis. The major differences between the adult and pediatric studies include the lack of association between tumor grade and IHC positivity in adults and the lack of detection of virus in a small number of adult non-tumor brain (Crawford et al. 2009ab). Contrary to our findings, Neves et al. reported no detectable HHV-6 in a series of non-paraffin-embedded normal cerebellum and pilocytic astrocytomas by quantitative PCR (Neves et al. 2008). Since few of our samples were primary PCR-positive for HHV-6, it is likely that CNS tumors harbor virus at very low levels. Although the concept of a neurotropic viral infection obtained during early childhood as a potential modifier in 
CNS neuro-oncogenesis is tempting, more work still needs to be done to determine what role, if any, HHV-6 plays in primary CNS brain tumors.

Human herpesvirus-7 and human herpesvirus- 8

Human herpesvirus-7 (HHV-7) and human herpesvirus8 (HHV-8) are relatively newly described herpesviruses with little published findings with regard to CNS malignancy. No seroprevalence data in conjunction with CNS tumors has been published to date on either virus. HHV-7 has been detected by PCR in 3\% (1/35) to $16 \%(14 / 88)$ of CNS tumors (Chan et al. 1999; Neves et al. 2008; Table 1). HHV-8 was not detected by PCR in a series of 35 pediatric pilocytic astrocytomas (Neves et al. 2008). More widespread serological and biological studies are necessary to determine whether HHV-7 and HHV-8 play a role in CNS brain tumors.

\section{Detection of polyomaviruses in primary CNS malignancies}

$\mathrm{JC}$ virus

The JCV was first discovered in 1971, isolated from the brain of a patient with progressive multifocal leukoencephalopathy, a degenerative, demyelinating disease (Padgett et al. 1971). Since then, the JCV has been found experimentally to be oncogenic in both animal models and human-derived cell lines (extensively reviewed in Croul et al. 2003; White et al. 2005; Barbanti-Brodano et al. 2006; Maginnis and Atwood 2009; Ahsan and Shah 2006; Jiang et al. 2009). The seroprevalence of JCV in the human population is estimated to range from around 19$50 \%$ and increases with age (Knowles et al. 2003).

A summary of the experimental approaches used in detection of JCV in human primary CNS tumors is summarized in Table 2. Researchers have largely employed PCR and Southern blot hybridization techniques for sensitive detection of JCV genome and IHC for the viral proteins. In the case of JCV, IHC has been used to detect both large T antigen (TAg) and agnoprotein, both involved in JCV oncogenesis. As summarized in Table 2, JCV has been detected in a wide variety of diverse CNS tumor subtypes. Of all studies which report JCV positivity by PCR, only oligodendroglioma (13/18), astrocytoma (14/ 26), ependymoma (5/18), GBM (19/34), and medulloblastoma $(22 / 39)$ were studied in sufficient quantity to have significance. Of all the studies, only four were done in pediatric CNS tumors (Boldorini et al. 1998; Krynska et al. 1999; Okamoto et al. 2005; Vasishta et al. 2009). The percentage of JCV IHC positivity is roughly half of that reported by PCR for each tumor subtype across the majority of both pediatric and adult studies employing both technologies. In the case of medulloblastoma, several researchers have failed to detect JCV by both PCR and IHC (Hayashi et al. 2001; Kim et al. 2002; Okamoto et al. 2005; Vasishta et al. 2009). The differences between the groups is not entirely clear and may be related to the sensitivities of the PCR methodologies used, as JCV DNA fragments (and not viral antigens) have been recently reported in a small series of normal human brain (Perez-Liz et al. 2008).

\section{BK virus}

First discovered in 1971, the BK virus was originally found in the urine of a renal transplant patient with renal stenosis (Gardner et al. 1971). Similar to JCV, BKV's oncogenicity in experimental animal models and association with human disease, namely hemorrhagic cystitis and polyomavirus nephropathy, has been well-studied and reviewed (Tognon et al. 2003; Fioriti et al. 2005; Yogo et al. 2009; Abend et al. 2009; Jiang et al. 2009). Opposite to JCV, BKV seroprevalence reaches around $90 \%$ in children 5 to 9 years and decreases in prevalence with advanced age (Knowles et al. 2003).

As was the case with JCV, BK virus has been detected in a wide variety of primary CNS tumor subtypes as shown in Table 2. BK virus has been detected in highest numbers by PCR in astrocytoma (16/17), ependymoma (10/11), and GBM (28/30) (Martini et al. 1996), while none has been detected in medulloblastoma (0/15; Kim et al. 2002). On the contrary, Arthur et al. were unable to detect BK virus in any of the 75 tumors tested by PCR (Arthur et al. 1994). IHC has not been performed on a large subset of CNS tumors, however, BK virus TAg has been reported in 8/10 glial tumors by RT-PCR (Martini et al. 1996).

\section{SV40 Virus}

The SV40 was first introduced into the human population through preparations of contaminated polio vaccines administered between the years 1955 and 1963. The natural host of SV40 is the rhesus macaque, and its horizontal transmission among humans as well as its causative role in human disease has come under question (Butel et al. 1997; Jasani et al. 2001; Klein et al. 2002; Gazdar et al. 2002; Carbone et al. 2003; Garcea 2001; Garcea and Imperiale 2003; Ahsan and Shah 2006; and Pipas 2009). The seroprevalence of SV40 is estimated to range from $1.3 \%$ to $5 \%$ in groups of all ages (Knowles et al. 2003). As shown in Table 2, the overall percentage of tumors positive for SV40 by PCR is lower than reported for the other polyomaviruses. The lower-grade tumors (choroid plexus papilloma, astrocytoma, meningioma, ependymoma) tended 
Table 2 Detection of polyomaviruses in primary central nervous system malignancy

\begin{tabular}{|c|c|c|c|c|c|}
\hline & \multicolumn{2}{|c|}{ Detected/sampled (\%) } & \multicolumn{3}{|c|}{ Detection method } \\
\hline & DNA & Proteins & DNA & Proteins & Reference \\
\hline \multicolumn{6}{|l|}{$\mathrm{JC}$ virus } \\
\hline Gangliocytoma & $0 / 1$ & $0 / 1$ & nPCR, PCR & IHC (TAg) & Boldorini et al. 2003 \\
\hline Choroid plexus papilloma & $1 / 5(20)$ & $1 / 5(20)$ & PCR, SB & IHC (TAg, Agno) & Okamoto et al. 2005 \\
\hline \multirow[t]{2}{*}{ Pilocytic astrocytoma } & $4 / 5(80)$ & $1 / 5(20)$ & PCR, SB & IHC (TAg) & Del Valle et al. 2001a, b \\
\hline & $0 / 7$ & $0 / 7$ & PCR, SB & IHC (TAg, Agno) & Okamoto et al. 2005 \\
\hline Subependymoma & $1 / 1(100)$ & $1 / 1(100)$ & PCR, SB & IHC (TAg) & Del Valle et al. 2001a, b \\
\hline Pleomorphic xanthoastrocytoma & $1 / 1(100)$ & - & $\mathrm{nPCR}$ & IHC (TAg) & Boldorini et al. 1998 \\
\hline \multirow[t]{4}{*}{ Oligodendroglioma } & $4 / 7(57)$ & - & PCR, SB & IHC (TAg) & Del Valle et al. 2001a, b \\
\hline & $13 / 18(72)$ & $8 / 18(44), 10 / 18(56)$ & PCR, SB & IHC (TAg, Agno) & Del Valle et al. 2002a \\
\hline & $1 / 2(50)$ & $1 / 2(50)$ & nPCR, PCR & IHC (TAg) & Boldorini et al. 2003 \\
\hline & $1 / 5(20)$ & $0 / 5$ & nPCR & IHC (TAg) & Caldarelli-Stefano et al. 2000 \\
\hline \multirow[t]{3}{*}{ Astrocytoma (all subtypes) } & $4 / 10(40)$ & $1 / 10(10)$ & nPCR & IHC (TAg) & Caldarelli-Stefano et al. 2000 \\
\hline & $1 / 3(33)$ & $1 / 3(33)$ & nPCR, PCR & IHC (TAg) & Boldorini et al. 2003 \\
\hline & $10 / 16(63)$ & $7 / 16(44)$ & PCR, SB & IHC (TAg) & Del Valle et al. 2001a, b \\
\hline \multirow[t]{4}{*}{ Ependyoma } & $5 / 6(83)$ & $4 / 6(67)$ & PCR, SB & IHC (TAg) & Del Valle et al. 2001a \\
\hline & $5 / 18(28)$ & 4/18 (22), 3/18 (17) & PCR, SB & IHC (TAg, Agno) & Okamoto et al. 2005 \\
\hline & $0 / 2$ & $0 / 2$ & nPCR, PCR & IHC (TAg) & Boldorini et al. 2003 \\
\hline & $1 / 5(20)$ & $0 / 5$ & nPCR & IHC (TAg) & Caldarelli-Stefano et al. 2000 \\
\hline \multirow[t]{2}{*}{ Oligoastrocytoma } & $5 / 8(63)$ & $2 / 8(25)$ & PCR, SB & IHC (TAg) & Del Valle et al. 2001a, b \\
\hline & $1 / 1(100)$ & $1 / 1(100)$ & PCR & IPPt (TAg) & Rencic et al. 1996 \\
\hline Anaplastic oligodendroglioma & $2 / 3(67)$ & $2 / 3(67)$ & PCR, SB & IHC (TAg) & Del Valle et al. 2001a, b \\
\hline Anaplastic astrocytoma & $3 / 4(75)$ & $0 / 4$ & PCR, SB & IHC (TAg) & Del Valle et al. 2001a, b \\
\hline \multirow[t]{2}{*}{ Anaplastic oligodendroglioma } & $2 / 3(67)$ & $2 / 3(67)$ & PCR, SB & IHC (TAg) & Del Valle et al. 2001a, b \\
\hline & $2 / 2(100)$ & $2 / 2(100), 1 / 2(50)$ & PCR, SB & IHC (TAg, Agno) & Del Valle et al. 2002a \\
\hline Gliomatosis cerebri & $1 / 1(100)$ & $1 / 1(100)$ & PCR, SB & IHC (TAg) & Del Valle et al. 2001a, b \\
\hline \multirow[t]{4}{*}{ GBM } & $12 / 21(57)$ & $5 / 21(24)$ & PCR, SB & IHC (TAg) & Del Valle et al. 2001a, b \\
\hline & $1 / 1(100)$ & $1 / 1(100)$ & PCR, SB & IHC (TAg) & Del Valle et al. 2000 \\
\hline & $7 / 13(54)$ & $7 / 13(54)$ & nPCR, PCR & IHC (TAg) & Boldorini et al. 2003 \\
\hline & $1 / 1(100)$ & 1/1 (100), 1/1 (100) & PCR & IHC (TAg, Agno) & Pina-Oviedo et al. 2006 \\
\hline \multirow[t]{6}{*}{ Medulloblastoma } & $11 / 16(68)$ & $9 / 16(56), 11 / 16(68)$ & PCR & IHC (TAg, Agno) & Del Valle et al. 2002b \\
\hline & $0 / 8$ & $0 / 8$ & PCR, SB & IHC (TAg) & Hayashi et al. 2001 \\
\hline & $11 / 23(48)$ & $4 / 23(17)$ & PCR, SB & IHC (TAg) & Krynska et al. 1999 \\
\hline & $0 / 15$ & $0 / 15$ & PCR, SB & IHC (TAg) & Kim et al. 2002 \\
\hline & - & $0 / 22$ & - & IHC (TAg, Agno) & Vasishta et al. 2009 \\
\hline & $0 / 32$ & $0 / 32$ & PCR, SB & IHC (TAg) & Okamoto et al. 2005 \\
\hline Pineoblastoma & $0 / 1$ & $0 / 1$ & nPCR, PCR & IHC (TAg) & Boldorini et al. 2003 \\
\hline Gliosarcoma & $1 / 1(100)$ & $1 / 1(100)$ & PCR, SB & IHC (TAg) & Del Valle et al. 2001a, b \\
\hline sPNET & $0 / 5$ & $0 / 5$ & PCR, SB & IHC (TAg) & Kim et al. 2002 \\
\hline \multicolumn{6}{|l|}{ BK virus } \\
\hline Choroid plexus papilloma & $6 / 6(100)$ & - & PCR, SB & & Martini et al. 1996 \\
\hline \multirow[t]{2}{*}{ Oligodendroglioma } & $1 / 1(100)$ & - & $\mathrm{SB}$ & & Dorries et al. 1987 \\
\hline & $7 / 9(78)$ & - & PCR, SB & & Martini et al. 1996 \\
\hline \multirow[t]{2}{*}{ Astrocytoma } & $0 / 3$ & - & $\mathrm{SB}$ & & Dorries et al. 1987 \\
\hline & 16/17 (94) & $1 / 1(100)$ & PCR, SB & RT-PCR (TAg) & Martini et al. 1996 \\
\hline \multirow[t]{2}{*}{ Ependymoma } & 10/11 (91) & - & PCR, SB & & Martini et al. 1996 \\
\hline & $2 / 3(60)$ & - & PCR, SB & & Negrini et al. 1990 \\
\hline Medulloblastoma & $0 / 15$ & $0 / 15$ & PCR, SB & IHC (TAg) & Kim et al. 2002 \\
\hline GBM & $0 / 75$ & - & PCR & & Arthur et al. 1994 \\
\hline
\end{tabular}


Table 2 (continued)

\begin{tabular}{|c|c|c|c|c|c|}
\hline & \multicolumn{2}{|c|}{ Detected/sampled (\%) } & \multicolumn{3}{|l|}{ Detection method } \\
\hline & $2 / 5(40)$ & - & SB & & Dorries et al. 1987 \\
\hline & $28 / 30(93)$ & 7/9 (78) & PCR, SB & RT-PCR (TAg) & Martini et al. 1996 \\
\hline \multirow[t]{2}{*}{ Brain tumor (mixed subtypes) } & $19 / 74(26)$ & - & SB & & Corallini et al. 1987 \\
\hline & $50 / 58(86)$ & - & PCR, SB & & De Mattei et al. 1995 \\
\hline \multirow[t]{2}{*}{ Meningioma } & $5 / 6(83)$ & - & SB & & Dorries et al. 1987 \\
\hline & 4/7 (57) & - & PCR, SB & & Martini et al. 1996 \\
\hline Neurinoma & $3 / 3(100)$ & - & $\mathrm{SB}$ & & Dorries et al. 1987 \\
\hline sPNET & $0 / 5$ & $0 / 5$ & PCR, SB & IHC (TAg) & Kim et al. 2002 \\
\hline \multicolumn{6}{|l|}{ Simian virus 40} \\
\hline \multirow[t]{6}{*}{ Choroid plexus papilloma } & $5 / 6(83)$ & - & PCR, SB & & Martini et al. 1996 \\
\hline & $10 / 20(50)$ & - & PCR, IHC (TAg) & & Bergsagel et al. 1992 \\
\hline & $6 / 16(38)$ & - & PCR, SB & & Huang et al. 1999 \\
\hline & - & $1 / 39(3)$ & IHC (TAg) & & Tabuchi et al. $1978 \mathrm{a}, \mathrm{b}$ \\
\hline & $10 / 13(77)$ & - & PCR & & Lednicky et al. 1995 \\
\hline & $1 / 14(7.1)$ & $0 / 7$ & PCR & RT-PCR & Engels et al. 2002 \\
\hline Subependymoma & $1 / 2(50)$ & - & PCR & & Weggen et al. 2000 \\
\hline \multirow[t]{3}{*}{ Oligodendroglioma } & $3 / 12(25)$ & - & PCR, SB & & Huang et al. 1999 \\
\hline & $0 / 9$ & - & PCR, SB & & Martini et al. 1996 \\
\hline & $1 / 3(33)$ & - & SB & & Krieg et al. 1981 \\
\hline \multirow[t]{4}{*}{ Astrocytoma (all subtypes) } & 8/17 (47) & - & PCR, SB & & Martini et al. 1996 \\
\hline & $0 / 3$ & - & $\mathrm{SB}$ & & Krieg et al. 1981 \\
\hline & $22 / 50(44)$ & - & PCR, SB & & Huang et al. 1999 \\
\hline & $1 / 8(13)$ & - & $\mathrm{SB}$ & & Krieg et al. 1981 \\
\hline \multirow[t]{5}{*}{ Ependymoma } & 10/11 (9) & - & PCR, IHC (TAg) & & Bergsagel et al. 1992 \\
\hline & - & $1 / 39(2.6)$ & IHC (TAg) & & Tabuchi et al., 1978a, b \\
\hline & $3 / 3(100)$ & - & PCR & & Lednicky et al. 1995 \\
\hline & 8/11 (73) & - & PCR, SB & & Martini et al. 1996 \\
\hline & $0 / 33$ & - & PCR & RT-PCR & Engels et al. 2002 \\
\hline Anaplastic ependymoma & $1 / 25(1)$ & - & PCR & & Weggen et al. 2000 \\
\hline Anaplastic meningioma & $1 / 131(1)$ & $0 / 131$ & PCR & IHC (TAg) & Weggen et al. 2000 \\
\hline \multirow[t]{4}{*}{ GBM } & $10 / 30(33)$ & - & PCR, SB & & Martini et al. 1996 \\
\hline & $0 / 3$ & - & $\mathrm{SB}$ & & Krieg et al. 1981 \\
\hline & $1 / 7(14)$ & - & D-DH & & Meinke et al. 1979 \\
\hline & $3 / 13(23)$ & - & PCR & IHC (TAg) & Kouhata et al. 2001 \\
\hline \multirow[t]{5}{*}{ Medulloblastoma } & $2 / 6(33)$ & $0 / 13$ & PCR & & Lednicky et al. 1995 \\
\hline & $5 / 17(29)$ & - & PCR, SB & & Huang et al. 1999 \\
\hline & $2 / 116(2)$ & $0 / 116$ & PCR & IHC (TAg) & Weggen et al. 2000 \\
\hline & $0 / 15$ & $0 / 15$ & PCR, SB & IHC (TAg) & Kim et al. 2002 \\
\hline & $1 / 2(50)$ & - & SB & & Krieg et al. 1981 \\
\hline \multirow[t]{2}{*}{ Meningioma } & 1/7 (14) & - & PCR, SB & & Martini et al. 1996 \\
\hline & $5 / 16(31)$ & - & $\mathrm{SB}$ & & Krieg et al. 1981 \\
\hline sPNET & $0 / 5$ & $0 / 5$ & PCR, SB & IHC (TAg) & Kim et al. 2002 \\
\hline
\end{tabular}

Abbreviations used: $P C R$ polymerase chain reaction, $R T-P C R$ real-time PCR, $n P C R$ nested PCR, IHC immunohistochemistry, $S B$ Southern blot, $I P P t$ immunoprecipitation, $D-D H$ DNA-DNA rehybridization kinetics, TAg T antigen, Agno agnoprotien, GBM glioblastoma multiforme, $s P N E T$ supratentorial primary neuroectodermal tumor 
to be more positive than the higher-grade tumors (GBM, anaplastic ependymoma, medulloblastoma, supratentorial PNET) with little known about $\mathrm{T}$ antigen expression by IHC. As with the other polyomaviruses, some groups have failed to detect SV40 DNA by PCR in ependymoma (0/30; Engels et al. 2002) and medulloblastoma (Kim et al. 2002), while Weggen et al. reported minimal detection of SV40 in meningioma (1/131) and medulloblastoma (2/116; Weggen et al. 2000).

\section{Detection of adenovirus in primary CNS malignancies}

Adenovirus is a human DNA virus that currently includes 51 serotypes and six species (Benko 2000; Shenk and Horwitz 2001) and has been shown to induce multiple tumors in newborn hamsters including neuroectodermal tumors and medulloblastoma (Yabe et al. 1962; Hohlweg et al. 2004). Kosulin et al. recently screened a series of 538 solid tumors and leukemias/lymphomas for the presence of adenovirus subtypes by real-time PCR and ISH (Kosulin et al. 2007). Adenovirus species were detected by PCR in ependymoma (20/30, species B,D,C), GBM (25/30, species B,D), and oligoastrocytoma (22/30, species B), while none were reported positive in astrocytoma, medulloblastoma, or germinoma. A subset of PCR-positive and PCR-negative samples were confirmed by ISH using adenovirus-specific probes. Among the adenoviral oncogenes detected in this study were E1A, EIB, and E4 ORF-1, the products or which have been shown to exhibit transforming capacity in animal models (White and Cipriani 1990; Shenk and Flint 1991; Javier 1994). A specific role, if any, of adenovirus infection in primary CNS tumors remains unclear since in the same study the authors report 11/20 normal brain harbor adenovirus DNA sequences (Kosulin et al. 2007).

\section{Molecular mechanisms of viral-mediated CNS neuro-oncomodulation}

\section{Alpha herpesviruses}

While few studies have been performed to investigate the prevalence of the alpha herpesviruses (HSV-1/2, VZV) in primary CNS tumors, aside from serological studies, this family of herpesviruses has been shown to interact with and regulate the retinoblastoma $(\mathrm{Rb})$ tumor suppressor pathway; a well-characterized pathway involved oncogenesis (Hayward et al. 2006; Hume and Kalejta 2009). As illustrated in Fig. 1, $\mathrm{Rb}$ is a transcriptional co-repressor (along with p107, p130) that regulates cellular proliferation and differentiation. During cellular senescence, the active hyperphosphorylated form of $\mathrm{Rb}$ binds to transcription factor E2F to repress transcriptional activity. In HSV-infected cells, Rb is held in its inactive hypophosphorylated state, possibly due to low cyclin-dependent kinase (CdK) activity. HSV-1, in particular, prevents $\mathrm{Rb}$ phosphorylation and through mislocalization, keeps CdK inactive. In the case of $\mathrm{VZV}, \mathrm{Rb}$ and $\mathrm{p} 107$ remain unphosphorylated, in spite of normal CdK activity. One report demonstrated that HSV-2-infected cells induced Rb phosphorylation (Hossain et al. 1997). However, since many of the in vitro studies of HSV-induced hypophosphorylation of $\mathrm{Rb}$ was performed in cycling cells, little is known about the effects of latent infection on cellular growth and differentiation in either CNS tumor cell lines or actual disease.

\section{Beta herpesviruses (CMV, HHV-6, and HHV-7)}

CMV is perhaps the most well-studied of the herpesviruses with regards to potential molecular mechanisms of neurooncogenesis. In particular, the term oncomodulation has been coined to describe how this virus could infect a tumor cell and increase its already malignant potential (Cinatl et al. 1996; Cinatl et al. 2004ab; Michaelis et al. 2009). With regard to oncomodulation in the CNS or neurooncomodulation, CMV infection has been shown to modify key molecular oncologic pathways including apoptosis, cell migration, angiogenesis, telomerase activity, and $\mathrm{Rb}$ tumor suppressor modulation (Michaelis et al. 2009) as outlined in Fig. 1. In contrast to the alphaherpesviruses, CMV induces a hyperphosphorylation of $\mathrm{Rb}$ following infection of senescent cells (Jault et al. 1995) by activating cyclin E and cyclin-B-dependent kinases. As a consequence of the hyperphosphorylation of Rb, E2F response genes are highly expressed, perhaps due to interaction with CMV immediate early protein 2 (Song and Stinski 2002).

In terms of apoptosis, CMV infection has been shown to prevent death in cancer cells (Michealis et al. Michaelis et al. 2004) through expression of numerous anti-apoptotic proteins (Goldmacher 2005). The CMV UL36 has been shown to inhibit Fas-mediated apoptosis via caspase 8 binding (Skaletskaya et al. 2001). CMV UL123/124 proteins have been shown to inhibit apoptosis by activating the PI3 kinase activity (Yu and Alwine 2002). CMV UL37 inhibits apoptosis by disrupting mitochondrial networks through an uncharacterized mechanism (McCormick et al. 2003). In addition to apoptotic mechanisms, CMV infection has been shown to increase smooth muscle cell migration, perhaps by beta- 1 alpha- 5 integrin-mediated binding to endothelin (Scholz et al. 2000) or in the case of glial cells, by an increase in AKT kinase activity (Cobbs et al. 2007, 2008). CMV may also promote oncogenesis by increasing telomerase activity, since human diploid cells and malignant cells infected with CMV show increased telomerase activity by stimulating hTERT gene expression (Straat et al. 2009). 


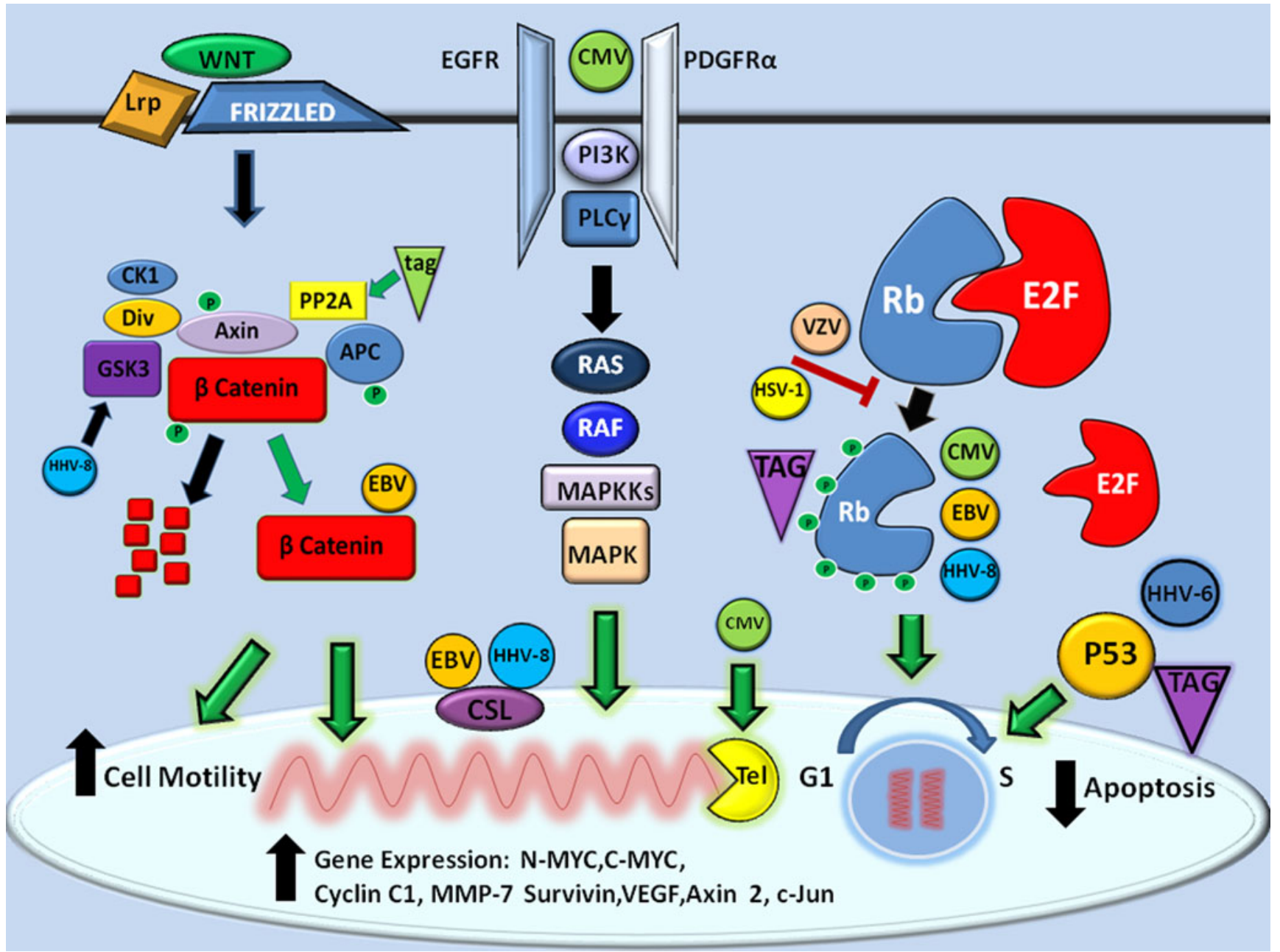

Fig. 1 Molecular mechanisms of CNS neuro-oncomodulation. The known proliferative molecular mechanisms of herpesvirus and polyomavirus infections on promoting gene expression, inhibition of apoptosis, and enhancing cell motility are shown (black arrows). In general, five major signaling pathways converge to promote onco-

In terms of angiogenesis, CMV-infected glial cell lines show downregulation of many negative regulators of angiogenesis including thrombospondin 1 and 2 (Cinatl et al. 1999, 2000). Tumor necrosis alpha, a proinflammatory cytokine known to stimulate angiogenic factors in gliomas (VEGF, IL8; Nabors et al. 2003), has also been reportedly increased following CMV infection of GBM cell lines (Baillie et al. 2003). Additionally, CMV has been shown to induce CD40 expression on the surface of infected cells, which, upon binding to CD40 ligand, results in increased VEGF production (Maisch et al. 2002). More recently, CMV has been shown to interact with the epidermal growth factor receptor (Wang et al. 2003) and platelet-derived growth factor receptor alpha (Soroceanu et al. 2008), two members of the receptor tyrosine kinase (RTK) family of receptors known to be upregulated in a number of primary CNS malignancies. While there is still some debate about the genesis for both families of viruses (green arrows), namely NOTCH/ WNT, receptor tyrosine kinase RTK (EGFR/PDGFR), telomerase $(\mathrm{Tel})$, retinoblastoma protein-E2F, and P53 pathways as described in the text

exact putative receptor of CMV-mediated entry and pathogenesis, modulation of either or both of the RTK pathways would help to support a role of CMV in neurooncogenesis. An indirect role for HCMV in neuro-oncomodulation is also possible, as HCMV has been shown to activate critical cell proliferative pathways in the absence of viral gene expression (Shibutani et al. 1997, Boyle et al. 1999, Johnson et al. 2000, 2001a, b).

Potential neuro-oncomodulatory mechanisms of chronic HHV-6 and HHV-7 infected CNS-derived cells are much less well-understood. Since HHV-6 has been shown to be chromosomally integrated in a subset of the population detected at birth (Hall et al. 2008), the role of chronic persistent infection on cellular proliferative mechanisms is not clear. One potential candidate is the HHV-6 viral oncogene that has been detected in human GBM by PCR and directly interacts with P53 (Kashanchi et al. 1997). 
Gamma herpesviruses

Although the gammaherpesviral infections have been reported predominantly in B cells, both EBV and HHV-8 are oncogenic viruses which directly interact with elements of two key regulatory pathways in neuro-oncogenesis, namely Notch and WNT (Fig. 1; Hayward et al. 2006). The Notch pathway is composed of a subfamily of receptors (Notch1-4) and ligands (Jagged1,2, Delta-like 1,3,4,), that upon binding of ligand to receptor results in cleavage of the intracellular Notch receptor domain (Notch IC). Notch IC then binds to CSL, a DNA binding protein and nuclear effector of the Notch pathway, displacing it and thus promoting transcription. EBV protein EBNA2 specifically interacts with CSL stimulating cellular proliferation and is necessary for the establishment of viral latency (Hayward et al. 2006). Similar to $\mathrm{EBV}, \mathrm{HHV}-8$ also interacts with CSL, but this interaction is critical for lytic infection as opposed to latency.

The WNT pathway is a complex pathway involving cell surface receptors, cytosolic complexes, and nuclear effectors, all designed to regulate cellular proliferation and differentiation. The WNT family of glycoproteins binds to the frizzled family of receptors and co-receptors (Lrp5/8) that ultimately results in the regulation of beta catenin, the nuclear effector of the WNT pathway, whose expression has been positively associated with a favorable prognosis in a number of CNS malignancies (Ellison et al. 2005; Rogers et al. 2009). The availability of nuclear beta catenin is dependent on the regulation of its phosphorylation by an extensive complex composed in part by APC, CKI, and GSK-3 (Fig. 1). In the phosphorylated state (promoted by both CKI and GSK-3), beta catenin is targeted for intracytosolic destruction by proteosome degradation. In the active non-phosphorylated state, beta catenin is responsible for the transcription of numerous neuroonco-proliferative genes including $\mathrm{C}$-myc, N-myc, cyclin C1, MMP-7, VEGF, surviving, axin 2, and cJun, among others (Hayward 2004). HHV-8 infection results in high cytoplasmic levels of beta catenin, due to its interaction with the HHV-8 latency-associated nuclear antigen (LANA). LANA causes dysregulation of beta catenin by inducing a nuclear translocation of GSK-3, essentially saving beta catenin from degradation. EBV similarly stabilizes beta catenin, through interactions with the EBV protein LMP-1, via unknown mechanisms.

The gammaherpesviruses also have regulatory interactions with the $\mathrm{Rb}$ pathway as per the other herpesviruses. EBV encodes many proteins (Z,R,LMP-1,EBNA-2,3C,S) that can lead to Rb phosphorylation by activation of cellular Cdk's or through direct phosphorylation by viral encoded kinases (Hayward et al. 2006, 2004). HHV-8 can similarly activate the $\mathrm{Rb}$ pathway by disruption of $\mathrm{Rb}-\mathrm{E} 2 \mathrm{~F}$ interactions mediated by LANA, v cyclin or HHV-8 ORF36-encoded proteins (Rajcani and Kudelova 2003; Hamza et al. 2004).
Polyomaviruses (BKV, JCV, and SV40)

Each of the polyomaviruses share similar oncogenic mechanisms via interactions between the two viral $T$ antigens (small T-tAG, large T-TAG) and key cellular regulatory pathways such as $\mathrm{P} 53$ and $\mathrm{Rb}$ as illustrated in Fig. 1 (Croul et al. 2003; Barbanti-Brodano et al. 2006; Lee and Langhoff 2006). The large TAG is the major oncogenic antigen and acts by directly increasing cell proliferation, inhibiting apoptosis, and damaging DNA. TAG has been shown to bind to unphosphorylated $\mathrm{Rb}$, causing release of E2F and subsequent cell cycle progression. Alternatively, TAG can modify $\mathrm{Rb}$ degradation pathways through binding of molecular chaperone protein hsp70 (Lee and Langhoff 2006). TAG has been shown to bind to P53 tumor suppressor protein, resulting in uncontrolled cellular proliferation and blockage of apoptosis (Harris et al. 1996). This may work through inhibition of p21/WAG-1, a stabilizing complex upstream of cyclin dependent kinase-cdK. Alternatively, TAG can also affect P53-mediated transcription without directly binding to P53 (Rushton et al 1997). Lastly, TAG can promote oncogenesis by causing direct chromosomal damage in cultured human cells infected with BK and SV40 viruses (Ray et al. 1990; Stewart and Bacchetti 1991; Trabanelli et al. 1998), or by interfering with topoisomerase I and helicase activities (Simmons et al. 1996; Dean et al. 1987).

Polyomavirus small $\mathrm{t}$ antigen (tAG) promotes cell division through interaction with PP2A and phosphatidylinositol 3-kinase regulatory pathways (Barbanti-Brodano et al. 2006; Fig. 1). tAG has been shown to inhibit PP2A function, a major regulator of the WNT/beta catenin pathway, by directly binding to both regulatory and catalytic PP2A domains (Garcea and Imperiale 2003; Barbanti-Bordano et al. 2004, 2006). As a consequence, the WNT pathway is inhibited and beta catenin is free to translocate to the nucleus to stimulate gene expression. In addition, PP2A inactivation by tAG affects cytoskeletal integrity and promotes tumor migration in epithelial cells (Nunbhakdi-Craig et al. 2003) infected with SV40 virus.

\section{Discussion}

The concept of viral-associated CNS malignancy has been met with appropriate skepticism from the scientific community. The major difficulties in establishing a more widespread acceptance of the concept of viral-mediated CNS disease are due in part to: lack of reproducible findings among researchers regarding viral detection in CNS tumors, paucity of animal model systems to study direct viral mechanisms of neuro-oncogenesis, high seroprevalence among controls and tumors alike, lack of stable 
detection of viruses in long-term cultures of human CNS tumors, and inability to induce transformation in noncancerous primary human CNS-derived cell lines.

Among potential possibilities to explain discrepancies of viral detection frequencies in CNS tumors between researchers includes tissue integrity, fixation conditions, tissue thickness, antibody dilution, incubation parameters, and PCR methodologies (Scheurer et al. 2008). For example, in the case of BKV and JCV, ultrasensitive nested PCR has been shown to have a sensitivity of ten genomes per viral copy (Bogdanovic et al. 1994). In the case of HHV-6, up to fivefold difference in detection sensitivity has been reported in a multicenter comparison among various PCR methodologies including nested PCR (Flamand et al. 2008). Unfortunately, in many cases, specific viral load quantification has not been performed with regard to CNS clinic specimens and the theoretical copy number sufficient to modify disease known. Another explanation for discrepancies of viral detection frequency is geographic distributions of latent CNS infections. However, given the widespread seropositivity worldwide, this seems less likely and difficult to prove unless viral genomic sequences are studied for region-specific polymorphisms. Since the CNS is a potential reservoir for many latent neurotropic viruses, it is difficult to assign causation by detection alone. Unfortunately, there has been no investigation of the frequency of viral genomic or antigen detection in a large diverse cohort of normal brain by serial anatomic sectioning to assess for anatomic tropism. This information is paramount to determine whether viral associations with CNS tumors are related to specific viral anatomic or cellular tropism versus a more global reactivation phenomenon associated with malignancy in general. For instance, in the case of JCV, it has been recently reported that JCV genomic segments but not proteins are present normal-appearing brain in a small series (Perez-Liz et al. 2008). Finding differences in genomic quantity or protein expression between CNS tumors and non-tumor CNS controls is critical in the establishment of a potential link between chronic viral infection and malignancy. Since many of the viruses establish latency in cells of hematopoetic origin, it is difficult without ISH or IHC methodologies to accurately confirm that positive PCR studies are exclusively of CNS origin. It is possible that propagation of viral macromolecules into the CNS could come via lymphocytes as suggested in the case of CMV by the high CMV detection in sera of patients with GBM (Mitchell et al. 2008).

In terms of animal models of neuro-oncogenesis BKV, SV40, and JC have all been shown to induce a number of CNS tumors in animal models, many of them correlating with the corresponding histological subtypes detected in human primary CNS tumors. For instance, BKV has been shown to induce ependymoma and choroid plexus papilloma in hamsters
(Barbanti-Brodano et al. 1998, 2004; Tognon et al. 2003) and has been detected in the corresponding subtypes in humans with high frequency (Negrini et al. 1990; Martini et al. 1996). Using the same animal model system, JCV inoculated intra-cerebrally induced mostly medulloblastoma in greater than $80 \%$ (Walker et al. 1973), suggesting that there may be a neuro-oncologic viral tropism. To date, JCV is the only polyomavirus able to induce CNS tumors in non-human primates. Following injection of JCV in squirrel monkeys, astrocytic tumors developed following a latency of 14 36 months (London et al 1978, 1983) and contained both integrated JCV DNA and expressed TAg protein (Miller et al. 1984; Major et al. 1984). These observations correlate with the detection of JCV DNA and TAg in human tumors that shows a predominance of JCV in CNS tumors of glial origin (Table 2). In the case of the herpesviruses, it is unclear whether the lack of malignant transformation in cell culture or in animal models is due to technical aspects of host infectivity versus a true lack of intrinsic neuro-oncogenic properties of viral infection. However, this does not rule out potential neuro-oncomodulatory mechanisms that may be contributing to pathogenesis of disease through epigenetic mechanisms.

The JCV primate data, while not conclusive for a role in human CNS tumorigenesis, does provide important insight into the potential time course and mechanisms of neurooncomodulation. The relatively short induction latency period before tumor formation in squirrel monkeys, when extracted to human lifespan is roughly between 10-20 years, suggestive of a chronic viral persistence as opposed to primary infection. In the case of acute infection, one would expect a sharp contrast in viral detection frequencies between adult and childhood CNS tumors, which has not been reported for either polyomaviruses or herpesviruses. Although, given the very high seroprevalence reported for both viruses at an early age, it would be very difficult to associate acute infection with malignancy based on epidemiology alone, making the concept of viral persistence more attractive in the case of neuro-oncomodulation as opposed to neuro-oncogenesis. In order for a virus to remain persistent in the CNS, it must replicate without killing the host and avoid the immunoprotective mechanisms designed to remove it (Oldstone 2009). It is possible these exact mechanisms used to avoid detection, may promote neurooncomodulation through common molecular pathways (Fig. 1). It is also conceivable that viral integrative mechanisms may promote oncogenesis alone in the absence of viral protein expression by insertion within key genomic regions.

A specific role of herpesviruses in primary CNS tumors remains to be determined and is met with similar skepticism as the polyomaviruses (Miller 2009). In the case of CMV, the theoretical neuro-oncogenic mechanisms are in question largely because of its inability to transform normal human cells in culture. From a more practical standpoint, the variance in detection frequency among researchers and the high 
seroprevalence makes it difficult to establish a firm association. One way to circumvent these critiques and demonstrate a functional role for CMV and other viruses in CNS tumors is to study the effect of treatment on disease. One example of this is the detection of CD8+ T cells in a GBM patient that were specific for the CMV protein pp65 following vaccination of autologous tumor lysate (Prins et al. 2008). Other clues to CMV's role are currently being studied in two clinical trials in patients with GBM treated with valganciclovir and CMV pp-65-modified dendritic cell vaccines (www.clinicaltrials. gov), the results of which are pending. While negative results do not necessarily exclude a role of viral infection in CNS malignancy for a number of reasons, an improvement in clinical outcome is supportive of such a hypothesis. Although even a positive correlation between treatment and survival could be explained by a secondary effect of treatment alone unrelated to viral infection.

In order establish a more widespread support for the role of viruses in either neuro-oncogenesis or neuro-oncomulation, much work needs to be done. First, there must be a more widespread cooperative validation of the multitude of PCR, ISH, and IHC techniques used in the detection of viral macromolecules. More importantly, the differences in viral detection among researchers must be more concretely explained through rigorous experimental approaches. Second, a better understanding of both regional and anatomic viral tropisms in normal brain of varying ages needs to be determined. The early and late effects of viral infection in CNS-derived cell lines would provide potential mechanisms of disease that could potentially be extrapolated to human CNS disease. Lastly, the design and implementation of new clinical trials directed at either targeting specific viral infections or modifying CNS neuroimmunity in favor of a cell-mediated or humoral-specific antiviral response is needed. Ultimately, a more thorough understanding of the neuroimmunology of CNS tumors is necessary to move the emerging field of neuro-viro-oncology forward.

Disclosures Both authors contributed equally to the work. The authors have nothing to disclose.

Open Access This article is distributed under the terms of the Creative Commons Attribution Noncommercial License which permits any noncommercial use, distribution, and reproduction in any medium, provided the original author(s) and source are credited.

\section{References}

Abend JR, Jiang M, Imperiale MJ (2009) BK virus and human cancer: innocent until proven guilty. Semin Cancer Biol $19: 252-260$
Ahsan N, Shah KV (2006) Polyomaviruses and human diseases. Adv Exp Med Biol 577:1-18

Arthur RR, Grossman SA, Ronnett BM, Bigner SH, Vogelstein B, Shah KV (1994) Lack of association of human polyomaviruses with human brain tumors. J Neurooncol 20:55-58

Arvin AG, Campadielli-Fiume E, Mocarski PS, Moore B, Roizman R, Whitley, Yamanishi K (eds) (2007) Human herpesviruses: biology, therapy, and immunoprophylaxis. Cambridge University Press, Cambridge

Baillie J, Sahlender DA, Sinclair JH (2003) Human cytomegalovirus infection inhibits tumor necrosis factor alpha (TNF-alpha) signaling by targeting the 55-kilodalton TNF-alpha receptor. J Virol 77:7007-7016

Barbanti-Brodano G, Martini F, De Mattei M, Lazzarin L, Corallini A, Tognon M (1998) BK and JC human polyomaviruses and simian virus 40: natural history of infection in humans, experimental oncogenicity, and association with human tumors. Adv Virus Res 50:69-99

Barbanti-Brodano G, Sabbioni S, Martini F, Negrini M, Corallini A, Tognon M (2004) Simian virus 40 infection in humans and association with human diseases: results and hypotheses. Virology 318:1-9

Barbanti-Brodano G, Sabbioni S, Martini F, Negrini M, Corallini A, Tognon M (2006) BK virus, JC virus and Simian virus 40 infection in humans, and association with human tumors. Adv Exp Med Biol 577:319-341

Benko M (2000) Comparison of the genome of ovine adenovirus types 1 through 5 by restriction enzyme analysis and DNA hybridisation. Acta Vet Hung 48:477-484

Bergsagel DJ, Finegold MJ, Butel JS, Kupsky WJ, Garcea RL (1992) DNA sequences similar to those of simian virus 40 in ependymomas and choroid plexus tumors of childhood. N Engl J Med 326:988-993

Bogdanovic G, Brytting $M$, Cinque $P$, Grandien $M$, Fridell E, Ljungman P, Lonnqvist B, Hammarin AL (1994) Nested PCR for detection of BK virus and JC virus DNA. Clin Diagn Virol 2:211-220

Boldorini R, Caldarelli-Stefano R, Monga G, Zocchi M, Mediati M, Tosoni A, Ferrante P (1998) PCR detection of JC virus DNA in the brain tissue of a 9-year-old child with pleomorphic xanthoastrocytoma. J Neurovirol 4:242-245

Boldorini R, Pagani E, Car PG, Omodeo-Zorini E, Borghi E, Tarantini L, Bellotti C, Ferrante P, Monga G (2003) Molecular characterisation of $\mathrm{JC}$ virus strains detected in human brain tumours. Pathology 35:248-253

Bondy ML, Scheurer ME, Malmer B, Barnholtz-Sloan JS, Davis FG, Il'yasova D, Kruchko C, McCarthy BJ, Rajaraman P, Schwartzbaum JA, Sadetzki S, Schlehofer B, Tihan T, Wiemels JL, Wrensch M, Buffler PA (2008) Brain tumor epidemiology: consensus from the brain tumor epidemiology consortium. Cancer 113:1953-1968

Boyle KA, Pietropaolo RL, Compton T (1999) Engagement of the cellular receptor for glycoprotein B of human cytomegalovirus activates the interferon-responsive pathway. Mol Cell Biol 19:3607-3613

Butel JS, Lednicky JA, Stewart AR, Garcea RL, Finegold MJ (1997) SV40 and human brain tumors. J Neurovirol 3(Suppl 1):S78-S79

Caldarelli-Stefano R, Boldorini R, Monga G, Meraviglia E, Zorini EO, Ferrante $\mathrm{P}$ (2000) JC virus in human glial-derived tumors. Hum Pathol 31:394-395

Carbone M, Bocchetta M, Cristaudo A, Emri S, Gazdar A, Jasani B, Lednicky J, Miele L, Mutti L, Pass HI, Ramael M, Rizzo P, Testa JR, Weggen S, Yeung A (2003) SV40 and human brain tumors. Int J Cancer 106:140-142, author reply 143-145

Caserta MT (2004) Human herpesvirus 6 infection of the central nervous system. Curr Infect Dis Rep 6:316-321 
CBTRUS (2009) CBTRUS Statistical Report: Primary brain and central nervous system tumors diagnosed in the United States in 2004-2005. Source: Central Brain Tumor Registry of the United States, Hinsdale, IL. website: www.cbtrus.org)

Chan PK, Ng HK, Cheng AF (1999) Detection of human herpesviruses 6 and 7 genomic sequences in brain tumours. J Clin Pathol $52: 620-623$

Cinatl J Jr, Cinatl J, Vogel JU, Rabenau H, Kornhuber B, Doerr HW (1996) Modulatory effects of human cytomegalovirus infection on malignant properties of cancer cells. Intervirology 39:259-269

Cinatl J Jr, Kotchetkov R, Scholz M, Cinatl J, Vogel JU, Driever PH, Doerr HW (1999) Human cytomegalovirus infection decreases expression of thrombospondin-1 independent of the tumor suppressor protein p53. Am J Pathol 155:285-292

Cinatl J Jr, Bittoova M, Margraf S, Vogel JU, Cinatl J, Preiser W, Doerr HW (2000) Cytomegalovirus infection decreases expression of thrombospondin-1 and -2 in cultured human retinal glial cells: effects of antiviral agents. J Infect Dis 182:643-651

Cinatl J Jr, Vogel JU, Kotchetkov R, Wilhelm Doerr H (2004a) Oncomodulatory signals by regulatory proteins encoded by human cytomegalovirus: a novel role for viral infection in tumor progression. FEMS Microbiol Rev 28:59-77

Cinatl J, Scholz M, Kotchetkov R, Vogel JU, Doerr HW (2004b) Molecular mechanisms of the modulatory effects of HCMV infection in tumor cell biology. Trends Mol Med 10:19-23

Clark DA, Ward KN (2008) Importance of chromosomally integrated HHV-6A and $-6 \mathrm{~B}$ in the diagnosis of active HHV-6 infection. Herpes 15:28-32

Cobbs CS, Harkins L, Samanta M, Gillespie GY, Bharara S, King PH, Nabors LB, Cobbs CG, Britt WJ (2002) Human cytomegalovirus infection and expression in human malignant glioma. Cancer Res 62:3347-3350

Cobbs CS, Soroceanu L, Denham S, Zhang W, Britt WJ, Pieper R, Kraus MH (2007) Human cytomegalovirus induces cellular tyrosine kinase signaling and promotes glioma cell invasiveness. J Neurooncol 85:271-280

Cobbs CS, Soroceanu L, Denham S, Zhang W, Kraus MH (2008) Modulation of oncogenic phenotype in human glioma cells by cytomegalovirus IE1-mediated mitogenicity. Cancer Res 68:724730

Corallini A, Pagnani M, Viadana P, Silini E, Mottes M, Milanesi G, Gerna G, Vettor R, Trapella G, Silvani V et al (1987) Association of BK virus with human brain tumors and tumors of pancreatic islets. Int J Cancer 39:60-67

Crawford JR, Santi MR, Cornelison R, Sallinen SL, Haapasalo H, MacDonald TJ (2009a) Detection of human herpesvirus-6 in adult central nervous system tumors: predominance of early and late viral antigens in glial tumors. J Neurooncol 95:49-60

Crawford JR, Santi MR, Thorarinsdottir HK, Cornelison R, Rushing EJ, Zhang H, Yao K, Jacobson S, Macdonald TJ (2009b) Detection of human herpesvirus- 6 variants in pediatric brain tumors: association of viral antigen in low grade gliomas. J Clin Virol 46:37-42

Croul S, Otte J, Khalili K (2003) Brain tumors and polyomaviruses. J Neurovirol 9:173-182

Cuomo L, Trivedi P, Cardillo MR, Gagliardi FM, Vecchione A, Caruso R, Calogero A, Frati L, Faggioni A, Ragona G (2001) Human herpesvirus 6 infection in neoplastic and normal brain tissue. J Med Virol 63:45-51

Dalianis T, Ramqvist T, Andreasson K, Kean JM, Garcea RL (2009) KI, WU and Merkel cell polyomaviruses: a new era for human polyomavirus research. Semin Cancer Biol 19:270-275

Davison AJ, Scott JE (1986) The complete DNA sequence of varicella-zoster virus. J Gen Virol 67(Pt 9):1759-1816

De Bolle L, Naesens L, De Clercq E (2005) Update on human herpesvirus 6 biology, clinical features, and therapy. Clin Microbiol Rev 18:217-245
De Mattei M, Martini F, Corallini A, Gerosa M, Scotlandi K, Carinci P, Barbanti-Brodano G, Tognon M (1995) High incidence of BK virus large-T-antigen-coding sequences in normal human tissues and tumors of different histotypes. Int J Cancer 61:756760

Dean FB, Bullock P, Murakami Y, Wobbe CR, Weissbach L, Hurwitz J (1987) Simian virus 40 (SV40) DNA replication: SV40 large T antigen unwinds DNA containing the SV40 origin of replication. Proc Natl Acad Sci USA 84:16-20

Del Valle L, Azizi SA, Krynska B, Enam S, Croul SE, Khalili K (2000) Reactivation of human neurotropic JC virus expressing oncogenic protein in a recurrent glioblastoma multiforme. Ann Neurol 48:932-936

Del Valle L, Baehring J, Lorenzana C, Giordano A, Khalili K, Croul S (2001a) Expression of a human polyomavirus oncoprotein and tumour suppressor proteins in medulloblastomas. Mol Pathol 54:331-337

Del Valle L, Gordon J, Assimakopoulou M, Enam S, Geddes JF, Varakis JN, Katsetos CD, Croul S, Khalili K (2001b) Detection of JC virus DNA sequences and expression of the viral regulatory protein T-antigen in tumors of the central nervous system. Cancer Res 61:4287-4293

Del Valle L, Delbue S, Gordon J, Enam S, Croul S, Ferrante P, Khalili $\mathrm{K}$ (2002a) Expression of JC virus T-antigen in a patient with MS and glioblastoma multiforme. Neurology 58:895-900

Del Valle L, Gordon J, Enam S, Delbue S, Croul S, Abraham S, Radhakrishnan S, Assimakopoulou M, Katsetos CD, Khalili K (2002b) Expression of human neurotropic polyomavirus JCV late gene product agnoprotein in human medulloblastoma. J Natl Cancer Inst 94:267-273

Dolan A, Jamieson FE, Cunningham C, Barnett BC, McGeoch DJ (1998) The genome sequence of herpes simplex virus type 2. J Virol 72:2010-2021

Duncan CG, Leary RJ, Lin JC et al (2009) Identification of microbial DNA in human cancer. BMC Med Genomics 2:22

Dorries K, Loeber G, Meixensberger J (1987) Association of polyomaviruses JC, SV40, and BK with human brain tumors. Virology 160:268-270

Ellison DW, Onilude OE, Lindsey JC, Lusher ME, Weston CL, Taylor RE, Pearson AD, Clifford SC (2005) beta-Catenin status predicts a favorable outcome in childhood medulloblastoma: the United Kingdom Children's Cancer Study Group Brain Tumour Committee. J Clin Oncol 23:7951-7957

Engels EA, Sarkar C, Daniel RW, Gravitt PE, Verma K, Quezado M, Shah KV (2002) Absence of simian virus 40 in human brain tumors from northern India. Int J Cancer 101:348-352

Fioriti D, Videtta M, Mischitelli M, Degener AM, Russo G, Giordano A, Pietropaolo V (2005) The human polyomavirus BK: potential role in cancer. J Cell Physiol 204:402-406

Flamand L, Gravel A, Boutolleau D, Alvarez-Lafuente R, Jacobson S, Malnati MS, Kohn D, Tang YW, Yoshikawa T, Ablashi D (2008) Multicenter comparison of PCR assays for detection of human herpesvirus 6 DNA in serum. J Clin Microbiol 46:2700-2706

Garcea RL (2001) SV40: a human pathogen? Dis Markers 17:149_ 151

Garcea RL, Imperiale MJ (2003) Simian virus 40 infection of humans. J Virol 77:5039-5045

Gardner SD, Field AM, Coleman DV, Hulme B (1971) New human papovavirus (B.K.) isolated from urine after renal transplantation. Lancet 1:1253-1257

Gazdar AF, Butel JS, Carbone M (2002) SV40 and human tumours: myth, association or causality? Nat Rev Cancer 2:957-964

GLOBOCAN (2002) Worldwide incidence and mortality of cancer, 2002 [computer program] IARC Press: Lyon, France

Goldmacher VS (2005) Cell death suppression by cytomegaloviruses. Apoptosis 10:251-265 
Gulley ML (2001) Molecular diagnosis of Epstein-Barr virus-related diseases. J Mol Diagn 3:1-10

Hall CB, Long CE, Schnabel KC, Caserta MT, McIntyre KM, Costanzo MA, Knott A, Dewhurst S, Insel RA, Epstein LG (1994) Human herpesvirus-6 infection in children. A prospective study of complications and reactivation. N Engl J Med 331:432438

Hall CB, Caserta MT, Schnabel KC, Long C, Epstein LG, Insel RA, Dewhurst S (1998) Persistence of human herpesvirus 6 according to site and variant: possible greater neurotropism of variant $\mathrm{A}$. Clin Infect Dis 26:132-137

Hall CB, Caserta MT, Schnabel K, Shelley LM, Marino AS, Carnahan JA, Yoo C, Lofthus GK, McDermott MP (2008) Chromosomal integration of human herpesvirus 6 is the major mode of congenital human herpesvirus 6 infection. Pediatrics 122:513520

Hamza MS, Reyes RA, Izumiya Y, Wisdom R, Kung HJ, Luciw PA (2004) ORF36 protein kinase of Kaposi's sarcoma herpesvirus activates the c-Jun N-terminal kinase signaling pathway. J Biol Chem 279:38325-38330

Harris KF, Christensen JB, Imperiale MJ (1996) BK virus large T antigen: interactions with the retinoblastoma family of tumor suppressor proteins and effects on cellular growth control. J Virol 70:2378-2386

Hayashi H, Endo S, Suzuki S, Tanaka S, Sawa H, Ozaki Y, Sawamura Y, Nagashima K (2001) JC virus large T protein transforms rodent cells but is not involved in human medulloblastoma. Neuropathology 21:129-137

Hayward SD (2004) Viral interactions with the Notch pathway. Semin Cancer Biol 14:387-396

Hayward SD, Liu J, Fujimuro M (2006) Notch and Wnt signaling: mimicry and manipulation by gamma herpesviruses. Sci STKE 2006, re4

Hohlweg U, Dorn A, Hosel M, Webb D, Buettner R, Doerfler W (2004) Tumorigenesis by adenovirus type 12 in newborn Syrian hamsters. Curr Top Microbiol Immunol 273:215-244

Hossain A, Holt T, Ciacci-Zanella J, Jones C (1997) Analysis of cyclin-dependent kinase activity after herpes simplex virus type 2 infection. J Gen Virol 78(Pt 12):3341-3348

Huang H, Reis R, Yonekawa Y, Lopes JM, Kleihues P, Ohgaki H (1999) Identification in human brain tumors of DNA sequences specific for SV40 large T antigen. Brain Pathol 9:33-42

Hume AJ, Kalejta RF (2009) Regulation of the retinoblastoma proteins by the human herpesviruses. Cell Div 4:1

Jasani B, Cristaudo A, Emri SA, Gazdar AF, Gibbs A, Krynska B, Miller C, Mutti L, Radu C, Tognon M, Procopio A (2001) Association of SV40 with human tumours. Semin Cancer Biol 11:49-61

Jault FM, Jault JM, Ruchti F, Fortunato EA, Clark C, Corbeil J, Richman DD, Spector DH (1995) Cytomegalovirus infection induces high levels of cyclins, phosphorylated $\mathrm{Rb}$, and $\mathrm{p} 53$, leading to cell cycle arrest. J Virol 69:6697-6704

Javier RT (1994) Adenovirus type 9 E4 open reading frame 1 encodes a transforming protein required for the production of mammary tumors in rats. J Virol 68:3917-3924

Jiang M, Abend JR, Johnson SF, Imperiale MJ (2009) The role of polyomaviruses in human disease. Virology 384:266-273

Johnson RA, Huong SM, Huang ES (2000) Activation of the mitogenactivated protein kinase $\mathrm{p} 38$ by human cytomegalovirus infection through two distinct pathways: a novel mechanism for activation of p38. J Virol 74:1158-1167

Johnson RA, Ma XL, Yurochko AD, Huang ES (2001a) The role of MKK1/2 kinase activity in human cytomegalovirus infection. J Gen Virol 82:493-497

Johnson RA, Wang X, Ma XL, Huong SM, Huang ES (2001b) Human cytomegalovirus up-regulates the phosphatidylinositol 3 - kinase (PI3-K) pathway: inhibition of PI3-K activity inhibits viral replication and virus-induced signaling. J Virol 75:6022-6032

Kashanchi F, Araujo J, Doniger J, Muralidhar S, Hoch R, Khleif S, Mendelson E, Thompson J, Azumi N, Brady JN, Luppi M, Torelli G, Rosenthal LJ (1997) Human herpesvirus 6 (HHV-6) ORF-1 transactivating gene exhibits malignant transforming activity and its protein binds to p53. Oncogene 14:359-367

Kim JY, Koralnik IJ, LeFave M, Segal RA, Pfister LA, Pomeroy SL (2002) Medulloblastomas and primitive neuroectodermal tumors rarely contain polyomavirus DNA sequences. Neuro Oncol 4:165-170

Kimberlin DW (2006) Diagnosis of herpes simplex virus in the era of polymerase chain reaction. Pediatr Infect Dis J 25:841-842

Klein G, Powers A, Croce C (2002) Association of SV40 with human tumors. Oncogene 21:1141-1149

Knowles WA, Pipkin P, Andrews N, Vyse A, Minor P, Brown DW, Miller E (2003) Population-based study of antibody to the human polyomaviruses $\mathrm{BKV}$ and $\mathrm{JCV}$ and the simian polyomavirus SV40. J Med Virol 71:115-123

Kosulin K, Haberler C, Hainfellner JA, Amann G, Lang S, Lion T (2007) Investigation of adenovirus occurrence in pediatric tumor entities. J Virol 81:7629-7635

Kouhata T, Fukuyama K, Hagihara N, Tabuchi K (2001) Detection of simian virus 40 DNA sequence in human primary glioblastomas multiforme. J Neurosurg 95:96-101

Krieg P, Amtmann E, Jonas D, Fischer H, Zang K, Sauer G (1981) Episomal simian virus 40 genomes in human brain tumors. Proc Natl Acad Sci U S A 78:6446-6450

Krynska B, Del Valle L, Croul S, Gordon J, Katsetos CD, Carbone M, Giordano A, Khalili K (1999) Detection of human neurotropic JC virus DNA sequence and expression of the viral oncogenic protein in pediatric medulloblastomas. Proc Natl Acad Sci USA 96:11519-11524

Lau SK, Chen YY, Chen WG, Diamond DJ, Mamelak AN, Zaia JA, Weiss LM (2005) Lack of association of cytomegalovirus with human brain tumors. Mod Pathol 18:838-843

Lednicky JA, Garcea RL, Bergsagel DJ, Butel JS (1995) Natural simian virus 40 strains are present in human choroid plexus and ependymoma tumors. Virology 212:710-717

Lee W, Langhoff E (2006) Polyomavirus in human cancer development. Adv Exp Med Biol 577:310-318

Liao JB (2006) Viruses and human cancer. Yale J Biol Med 79:115122

London WT, Houff SA, Madden DL, Fuccillo DA, Gravell M, Wallen WC, Palmer AE, Sever JL, Padgett BL, Walker DL, ZuRhein GM, Ohashi T (1978) Brain tumors in owl monkeys inoculated with a human polyomavirus (JC virus). Science 201:1246-1249

London WT, Houff SA, McKeever PE, Wallen WC, Sever JL, Padgett BL, Walker DL (1983) Viral-induced astrocytomas in squirrel monkeys. Prog Clin Biol Res 105:227-237

Luppi M, Barozzi P, Maiorana A, Marasca R, Trovato R, Fano R, Ceccherini-Nelli L, Torelli G (1995) Human herpesvirus-6: a survey of presence and distribution of genomic sequences in normal brain and neuroglial tumors. J Med Virol 47:105-111

Maginnis MS, Atwood WJ (2009) JC virus: an oncogenic virus in animals and humans? Semin Cancer Biol 19:261-269

Maisch T, Kropff B, Sinzger C, Mach M (2002) Upregulation of CD40 expression on endothelial cells infected with human cytomegalovirus. J Virol 76:12803-12812

Major EO, Mourrain P, Cummins C (1984) JC virus-induced owl monkey glioblastoma cells in culture: biological properties associated with the viral early gene product. Virology 136:359367

Martini F, Iaccheri L, Lazzarin L, Carinci P, Corallini A, Gerosa M, Iuzzolino P, Barbanti-Brodano G, Tognon M (1996) SV40 early 
region and large $\mathrm{T}$ antigen in human brain tumors, peripheral blood cells, and sperm fluids from healthy individuals. Cancer Res 56:4820-4825

McCormick AL, Smith VL, Chow D, Mocarski ES (2003) Disruption of mitochondrial networks by the human cytomegalovirus UL37 gene product viral mitochondrion-localized inhibitor of apoptosis. J Virol 77:631-641

McGeoch DJ, Dalrymple MA, Davison AJ, Dolan A, Frame MC, McNab D, Perry LJ, Scott JE, Taylor P (1988) The complete DNA sequence of the long unique region in the genome of herpes simplex virus type 1. J Gen Virol 69(Pt 7):1531-1574

Meinke W, Goldstein DA, Smith RA (1979) Simian virus 40-related DNA sequences in a human brain tumor. Neurology 29:1590 1594

Michaelis M, Kotchetkov R, Vogel JU, Doerr HW, Cinatl J Jr (2004) Cytomegalovirus infection blocks apoptosis in cancer cells. Cell Mol Life Sci 61:1307-1316

Michaelis M, Doerr HW, Cinatl J Jr (2009) Oncomodulation by human cytomegalovirus: evidence becomes stronger. Med Microbiol Immunol 198:79-81

Miller G (2009) Brain cancer. A viral link to glioblastoma? Science 323:30-31

Miller NR, McKeever PE, London W, Padgett BL, Walker DL, Wallen WC (1984) Brain tumors of owl monkeys inoculated with JC virus contain the JC virus genome. J Virol 49:848-856

Mitchell DA, Xie W, Schmittling R, Learn C, Friedman A, McLendon RE, Sampson JH (2008) Sensitive detection of human cytomegalovirus in tumors and peripheral blood of patients diagnosed with glioblastoma. Neuro Oncol 10:10-18

Nabors LB, Suswam E, Huang Y, Yang X, Johnson MJ, King PH (2003) Tumor necrosis factor alpha induces angiogenic factor upregulation in malignant glioma cells: a role for RNA stabilization and HuR. Cancer Res 63:4181-4187

Negrini M, Rimessi P, Mantovani C, Sabbioni S, Corallini A, Gerosa MA, Barbanti-Brodano G (1990) Characterization of BK virus variants rescued from human tumours and tumour cell lines. J Gen Virol 71(Pt 11):2731-2736

Neves AM, Thompson G, Carvalheira J, Trindade JC, Rueff J, Caetano JM, Casey JW, Hermouet S (2008) Detection and quantitative analysis of human herpesvirus in pilocytic astrocytoma. Brain Res 1221:108-114

Nunbhakdi-Craig V, Craig L, Machleidt T, Sontag E (2003) Simian virus 40 small tumor antigen induces deregulation of the actin cytoskeleton and tight junctions in kidney epithelial cells. J Virol 77:2807-2818

Okamoto H, Mineta T, Ueda S, Nakahara Y, Shiraishi T, Tamiya T, Tabuchi K (2005) Detection of JC virus DNA sequences in brain tumors in pediatric patients. J Neurosurg 102:294-298

Okuno T, Takahashi K, Balachandra K, Shiraki K, Yamanishi K, Takahashi M, Baba K (1989) Seroepidemiology of human herpesvirus 6 infection in normal children and adults. J Clin Microbiol 27:651-653

Oldstone MB (2009) Anatomy of viral persistence. PLoS Pathog 5: e1000523

Padgett BL, Walker DL, ZuRhein GM, Eckroade RJ, Dessel BH (1971) Cultivation of papova-like virus from human brain with progressive multifocal leucoencephalopathy. Lancet 1:1257-1260

Parkin DM, Whelan SL, Ferlay J, Teppo L, Thomas DB (2002) Cancer in five continents vol. 5. IARC Press, Lyon

Perez-Liz G, Del Valle L, Gentilella A, Croul S, Khalili K (2008) Detection of JC virus DNA fragments but not proteins in normal brain tissue. Ann Neurol 64:379-387

Pina-Oviedo S, De Leon-Bojorge B, Cuesta-Mejias T, White MK, Ortiz-Hidalgo C, Khalili K, Del Valle L (2006) Glioblastoma multiforme with small cell neuronal-like component: association with human neurotropic JC virus. Acta Neuropathol 111:388-396
Pipas JM (2009) SV40: cell transformation and tumorigenesis. Virology 384:294-303

Poltermann S, Schlehofer B, Steindorf K, Schnitzler P, Geletneky K, Schlehofer JR (2006) Lack of association of herpesviruses with brain tumors. J Neurovirol 12:90-99

Prins RM, Cloughesy TF, Liau LM (2008) Cytomegalovirus immunity after vaccination with autologous glioblastoma lysate. N Engl $\mathrm{J}$ Med 359:539-541

Rajcani J, Kudelova M (2003) Gamma herpesviruses: pathogenesis of infection and cell signaling. Folia Microbiol (Praha) 48:291-318

Ray FA, Peabody DS, Cooper JL, Cram LS, Kraemer PM (1990) SV40 $\mathrm{T}$ antigen alone drives karyotype instability that precedes neoplastic transformation of human diploid fibroblasts. J Cell Biochem 42:13-31

Rencic A, Gordon J, Otte J, Curtis M, Kovatich A, Zoltick P, Khalili K, Andrews D (1996) Detection of JC virus DNA sequence and expression of the viral oncoprotein, tumor antigen, in brain of immunocompetent patient with oligoastrocytoma. Proc Natl Acad Sci USA 93:7352-7357

Rogers HA, Miller S, Lowe J, Brundler MA, Coyle B, Grundy RG (2009) An investigation of WNT pathway activation and association with survival in central nervous system primitive neuroectodermal tumours (CNS PNET). Br J Cancer 100:12921302

Rollison DE (2006) Epidemiologic studies of polyomaviruses and cancer: previous findings, methodologic challenges and future directions. Adv Exp Med Biol 577:342-356

Rollison DE, Helzlsouer KJ, Alberg AJ, Hoffman S, Hou J, Daniel R, Shah KV, Major EO (2003) Serum antibodies to JC virus, BK virus, simian virus 40 , and the risk of incident adult astrocytic brain tumors. Cancer Epidemiol Biomarkers Prev $12: 460-463$

Rushton JJ, Jiang D, Srinivasan A, Pipas JM, Robbins PD (1997) Simian virus $40 \mathrm{~T}$ antigen can regulate $\mathrm{p} 53$-mediated transcription independent of binding p53. J Virol 71:5620-5623

Sabatier J, Uro-Coste E, Pommepuy I, Labrousse F, Allart S, Tremoulet M, Delisle MB, Brousset P (2005) Detection of human cytomegalovirus genome and gene products in central nervous system tumours. Br J Cancer 92:747-750

Scheurer ME, El-Zein R, Bondy ML, Harkins L, Cobbs CS (2007) RE: "Lack of association of herpesviruses with brain tumors". J Neurovirol 13:85; author reply 86-87

Scheurer ME, Bondy ML, Aldape KD, Albrecht T, El-Zein R (2008) Detection of human cytomegalovirus in different histological types of gliomas. Acta Neuropathol 116:79-86

Scholz M, Blaheta RA, Wittig B, Cinatl J, Vogel JU, Doerr HW, Cinatl J Jr (2000) Cytomegalovirus-infected neuroblastoma cells exhibit augmented invasiveness mediated by beta1alpha5 integrin (VLA-5). Tissue Antigens 55:412-421

Shenk T, Flint J (1991) Transcriptional and transforming activities of the adenovirus E1A proteins. Adv Cancer Res 57:47-85

Shenk T, Horwitz MS (2001) Adenoviridae: the viruses and their replication; adenoviruses. In: Knipe DM, Howley PM, Griffin DE, Lamb RA, Martin MA, Roizman B, Straus SE (eds) Fields Virology, 4th edn. Williams \& Wilkins, Philadelphia, pp 22652326

Shibutani T, Johnson TM, Yu ZX, Ferrans VJ, Moss J, Epstein SE (1997) Pertussis toxin-sensitive G proteins as mediators of the signal transduction pathways activated by cytomegalovirus infection of smooth muscle cells. J Clin Invest 100:2054-2061

Simmons DT, Melendy T, Usher D, Stillman B (1996) Simian virus 40 large $\mathrm{T}$ antigen binds to topoisomerase I. Virology 222:365-374

Skaletskaya A, Bartle LM, Chittenden T, McCormick AL, Mocarski ES, Goldmacher VS (2001) A cytomegalovirus-encoded inhibitor of apoptosis that suppresses caspase-8 activation. Proc Natl Acad Sci U S A 98:7829-7834 
Song YJ, Stinski MF (2002) Effect of the human cytomegalovirus IE86 protein on expression of E2F-responsive genes: a DNA microarray analysis. Proc Natl Acad Sci U S A 99:2836-2841

Soroceanu L, Akhavan A, Cobbs CS (2008) Platelet-derived growth factor-alpha receptor activation is required for human cytomegalovirus infection. Nature 455:391-395

Stewart N, Bacchetti S (1991) Expression of SV40 large T antigen, but not small $\mathrm{t}$ antigen, is required for the induction of chromosomal aberrations in transformed human cells. Virology 180:49-57

Straat K, Liu C, Rahbar A, Zhu Q, Liu L, Wolmer-Solberg N, Lou F, Liu Z, Shen J, Jia J, Kyo S, Bjorkholm M, Sjoberg J, SoderbergNaucler C, Xu D (2009) Activation of telomerase by human cytomegalovirus. J Natl Cancer Inst 101:488-497

Tabuchi K, Kirsch WM, Low M, Gaskin D, Van Buskirk J, Maa S (1978a) Screening of human brain tumors for SV40-related T antigen. Int J Cancer 21:12-17

Tabuchi K, Kirsch WM, Van Buskirk JJ (1978b) Immunocytochemical evidence of SV 40-related $\mathrm{T}$ antigen in two human brain tumours of ependymal origin. Acta Neurochir (Wien) 43:239 249

Tognon M, Corallini A, Martini F, Negrini M, Barbanti-Brodano G (2003) Oncogenic transformation by BK virus and association with human tumors. Oncogene 22:5192-5200

Trabanelli C, Corallini A, Gruppioni R, Sensi A, Bonfatti A, Campioni D, Merlin M, Calza N, Possati L, Barbanti-Brodano G (1998) Chromosomal aberrations induced by BK virus $T$ antigen in human fibroblasts. Virology 243:492-496

Vasishta RK, Pasricha N, Nath A, Sehgal S (2009) The absence of JC virus antigens in Indian children with medulloblastomas. Indian $\mathrm{J}$ Pathol Microbiol 52:42-45

Volpi A (2004) Epstein-Barr virus and human herpesvirus type 8 infections of the central nervous system. Herpes 11(Suppl 2): $120 \mathrm{~A}-127 \mathrm{~A}$

Walker DL, Padgett BL, ZuRhein GM, Albert AE, Marsh RF (1973) Human papovavirus (JC): induction of brain tumors in hamsters. Science 181:674-676

Wang X, Huong SM, Chiu ML, Raab-Traub N, Huang ES (2003) Epidermal growth factor receptor is a cellular receptor for human cytomegalovirus. Nature 424:456-461

Weggen S, Bayer TA, von Deimling A, Reifenberger G, von Schweinitz D, Wiestler OD, Pietsch T (2000) Low frequency of SV40, JC and $\mathrm{BK}$ polyomavirus sequences in human medulloblastomas, meningiomas and ependymomas. Brain Pathol 10:85-92

White E, Cipriani R (1990) Role of adenovirus E1B proteins in transformation: altered organization of intermediate filaments in transformed cells that express the 19-kilodalton protein. Mol Cell Biol 10:120-130

White MK, Gordon J, Reiss K, Del Valle L, Croul S, Giordano A, Darbinyan A, Khalili K (2005) Human polyomaviruses and brain tumors. Brain Res Brain Res Rev 50:69-85

Wrensch M, Weinberg A, Wiencke J, Masters H, Miike R, Barger G, Lee M (1997) Does prior infection with varicella-zoster virus influence risk of adult glioma? Am J Epidemiol 145:594-597

Wrensch M, Weinberg A, Wiencke J, Miike R, Barger G, Kelsey K (2001) Prevalence of antibodies to four herpesviruses among adults with glioma and controls. Am J Epidemiol 154:161-165

Wrensch M, Minn Y, Chew T, Bondy M, Berger MS (2002) Epidemiology of primary brain tumors: current concepts and review of the literature. Neuro Oncol 4:278-299

Wrensch M, Weinberg A, Wiencke J, Miike R, Sison J, Wiemels J, Barger G, DeLorenze G, Aldape K, Kelsey K (2005) History of chickenpox and shingles and prevalence of antibodies to varicella-zoster virus and three other herpesviruses among adults with glioma and controls. Am J Epidemiol 161:929-938

Yabe Y, Trentin JJ, Taylor G (1962) Cancer induction in hamsters by human type 12 adenovirus. Effect of age and of virus dose. Proc Soc Exp Biol Med 111:343-344

Yamanishi K, Okuno T, Shiraki K, Takahashi M, Kondo T, Asano Y, Kurata T (1988) Identification of human herpesvirus-6 as a causal agent for exanthem subitum[see comment]. Lancet 1:1065-1067

Yogo Y, Sugimoto C, Zhong S, Homma Y (2009) Evolution of the BK polyomavirus: epidemiological, anthropological and clinical implications. Rev Med Virol 19:185-199

Yoshikawa T, Asano Y, Akimoto S, Ozaki T, Iwasaki T, Kurata T, Goshima F, Nishiyama Y (2002) Latent infection of human herpesvirus 6 in astrocytoma cell line and alteration of cytokine synthesis. J Med Virol 66:497-505

Yu Y, Alwine JC (2002) Human cytomegalovirus major immediateearly proteins and simian virus 40 large $\mathrm{T}$ antigen can inhibit apoptosis through activation of the phosphatidylinositide $3^{\prime}-\mathrm{OH}$ kinase pathway and the cellular kinase Akt. J Virol 76:37313738

Zerr DM, Meier AS, Selke SS, Frenkel LM, Huang ML, Wald A, Rhoads MP, Nguy L, Bornemann R, Morrow RA, Corey L (2005) A population-based study of primary human herpesvirus 6 infection. N Engl J Med 352:768-776

zur Hausen H (2008) Novel human polyomaviruses-re-emergence of a well known virus family as possible human carcinogens. Int $\mathrm{J}$ Cancer 123:247-250 